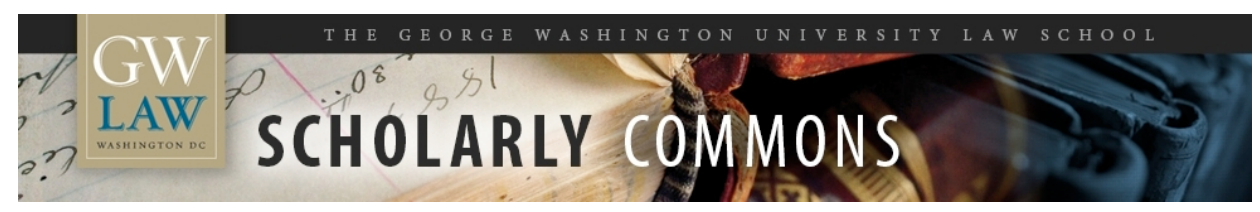

\title{
The Uneasy Case for Patent Races Over Auctions
}

Michael B. Abramowicz

George Washington University Law School, abramowicz@law.gwu.edu

Follow this and additional works at: https://scholarship.law.gwu.edu/faculty_publications

Part of the Law Commons

\section{Recommended Citation}

Michael Abramowicz, The Uneasy Case for Patent Races Over Auctions, 60 Stan. L. Rev. 803 (2007)

This Article is brought to you for free and open access by the Faculty Scholarship at Scholarly Commons. It has been accepted for inclusion in GW Law Faculty Publications \& Other Works by an authorized administrator of Scholarly Commons. For more information, please contact spagel@law.gwu.edu. 


\title{
The Uneasy Case for Patent Races over Auctions
}

\author{
by Michael Abramowicz*
}

In advancing his prospect theory of patents, Edmund Kitch dismissed the possibility of distributing rights to particular inventions through auctions, arguing that the patent system avoids the need for governmental officials to define the boundaries of inventions that have not yet been created. Auctions for patent rights to entire inventive fields, however, might accentuate the benefits of a prospect approach, by allowing for earlier and broader patents. Auction designs that award the patent to the bidder that commits the most money to research and development or that agrees to charge the lowest price, meanwhile, can reduce the costs of the prospect approach. Concerns about the government's ability to decide correctly when to hold auctions, however, provide an uneasy case for patent races over patent auctions. More modest uses of auctions might improve welfare, though. For example, an auction to a small number of parties of the right to race in a technological field might reduce wasteful duplication and thus accelerate innovation. Similarly, patentees might be allowed to demand auctions for extended patent scope, with the caveat that a patentee would need to outbid others by a substantial amount to win such an auction.

INTRODUCTION .2

I. A Brief Intellectual History of Patent Auctions ........................................

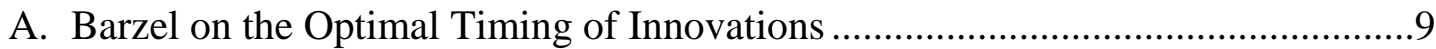

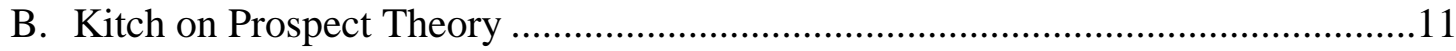

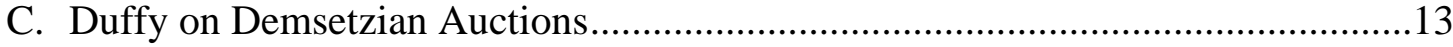

D. Bar-Gill and Parchomovsky on Auctioning Ideas ...............................................16

II. The Uneasy Case for Patent Races over Patent Auctions ..............................20

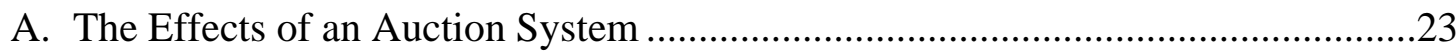

1. Enablement of Expansive Patent Scope....................................................24

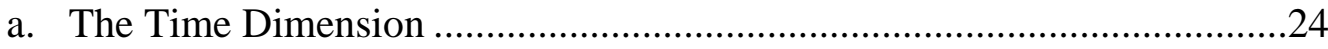

b. The Technology Dimension...................................................................25

2. Effects of Expansive Patent Scope ...........................................................27

a. Effects on Invention and Development Incentives .................................27

b. Effects on Deadweight Loss ...............................................................29

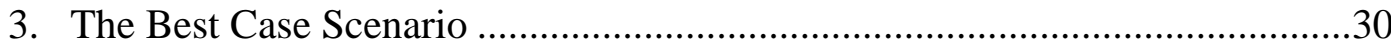

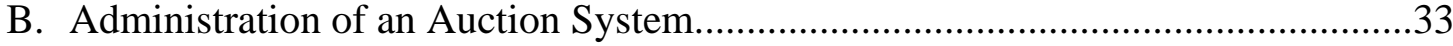

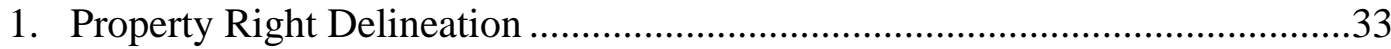

\footnotetext{
* Associate Professor, George Washington University Law School. J.D., Yale Law School; B.A., Amherst College. For helpful suggestions, I am grateful to Omer Alper, Ian Ayres, Sam Dinkin, Rebecca Eisenberg, Scott Hemphill, Douglas Lichtman, Richard Pierce, and Peter Swire, as well as participants in workshops at Boston University School of Law, Columbia Law School, the CNA Corporation, George Washington University Law School, the University of Chicago Law School, and the University of Michigan Law School. I am especially indebted to John Duffy for valuable comments and discussion.
} 


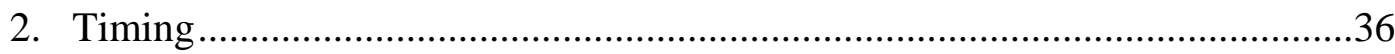

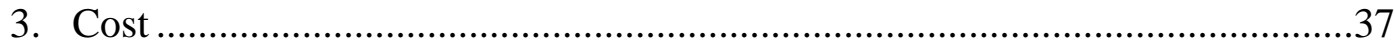

C. Additional Objections and Caveats....................................................................39

1. International Cooperation ................................................................................39

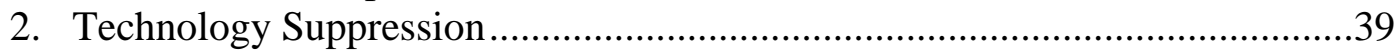

3. Irrational and Mistaken Bids.........................................................................41

4. Small and Independent Inventors...................................................................42

III. THE DeSIGN OF PATENT Auctions ………………….................................................43

A. Auctions to Stimulate Development .................................................................44

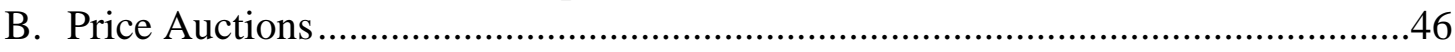

1. Least Patent Term Auctions ........................................................................46

2. Price Auctions ......................................................................................................49

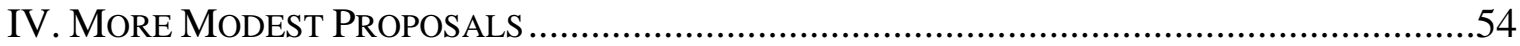

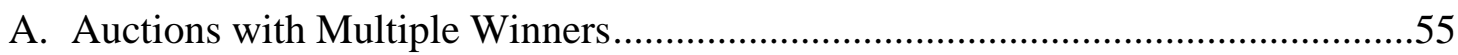

B. Patent Scope Auctions ……………………………………………………….....56

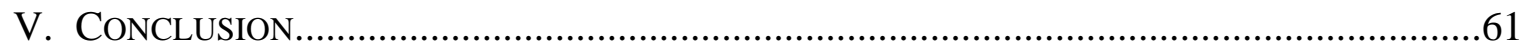

\section{INTRODUCTION}

The government awards intellectual property rights based on a principle analogous to that of first possession. The author who creates a literary work enjoys copyright protection, ${ }^{1}$ the entrepreneur who first uses an indication of origin receives a trademark, ${ }^{2}$ and the first inventor of a useful machine or process is entitled to apply for a patent. ${ }^{3}$ This approach is not inevitable. Other property rights initially conferred by the government are assigned by administrative fiat or through auction. For example, the Federal Communications Commission decides who may use some parts of the broadcast spectrum and auctions rights to other frequencies. ${ }^{4}$ Economists,

\footnotetext{
${ }^{1}$ Under the Copyright Act, "Copyright protection subsists . . . in original works of authorship fixed in any tangible medium of expression.” 17 U.S.C. § 102(a) (2000). A caveat is that in theory, someone independently could originate the exact same work and be entitled to a copyright too. See Sheldon v. Metro-Goldwyn Pictures Corp., 81 F.2d 49, 54 (2d Cir. 1936) (Hand, J.) (noting that 'if by some magic a man who had never known it were to compose anew Keats's 'Ode on a Grecian Urn,' he would be entitled to copyright protection). That, however, virtually never happens in practice, because of the large number of ways in which ideas can be expressed.

${ }^{2}$ Under the Lanham Act, the term "trademark" includes "any word, name, symbol, or device, or any combination thereof ... . used by a person, or . . . which a person has a bona fide intention to use in commerce and applies to register.” 15 U.S.C. § 1127.

${ }^{3}$ The Patent Act provides, "Whoever invents or discovers any new and useful process, machine, manufacture, or composition of matter, or any new and useful improvement thereof, may obtain a patent therefore, subject to the conditions and requirements of this title.” 35 U.S.C. $\S 101$.

4 The most famous article urging a shift from the administrative approach to auctions is Ronald H. Coase, The Federal Communications Commission, 2 J.L. \& ECON. 1 (1959), which included a brief version of what would later be known as the Coase Theorem. For a later analysis, see Thomas W. Hazlett, The Rationality of U.S. Regulation of the Broadcast Spectrum, 33
} 
meanwhile, have suggested that auctions be used to limit participation in research tournaments, such as competitions to design the best fighter jet for the government. ${ }^{5}$ Despite the similarities between research tournaments and patent races, ${ }^{6}$ commentators have paid virtually no attention to the possibility that intellectual property rights might be auctioned. ${ }^{7}$ In theory, the government could auction a particular class of intellectual property rights encompassing copyrighted works, trademarks, or inventions yet to be created..$^{8}$ The winner of such an auction would then have incentives to create intellectual property within the scope of the right, without needing to worry that competition from third parties might make the investments worthless.

This Article considers whether auctioning patents, instead of (or in addition to) granting them to the first inventors, could accelerate innovation and improve efficiency. The debate will turn on a variety of empirical considerations, many of which will be familiar from the debate on Edmund Kitch's prospect theory of patent law, ${ }^{9}$ which suggests that broad patents should generally be granted after relatively little inventive accomplishment. ${ }^{10}$ Critics of prospect theory argue that prospects might harm innovation by muting competitive pressures ${ }^{11}$ and centralizing

J.L. \& ECON. 133 (1990).

${ }^{5}$ See, e.g., Richard L. Fullerton \& R. Preston McAfee, Auctioning Entry into Tournaments, 107 J. PoL. EcON. 573, 581 (1999) (showing that under certain conditions, an auction should be used to limit a research tournament to the two participants willing to pay the most for the right to participate).

${ }^{6}$ The difference is that "in a research tournament, the terminal date is fixed, and the quality of innovations varies, while in an innovation race, the quality standard is fixed, and the date of discovery is variable.” Curtis R. Taylor, Digging for Golden Carrots: An Analysis of Research Tournaments, 85 AM. ECON. REV. 872, 874 (1995).

7 A notable exception is Gideon Parchomovsky's proposal for using auctions to distribute domain names. See Gideon Parchomovsky, Trademarks, Domain Names, and Internal Auctions, 2001 U. ILl. L. Rev. 211 (2001). No one appears to have considered auctioning rights to genres of copyrighted works, and such broad copyrights would almost certainly be unattractive on economic and free speech grounds. See Michael Abramowicz, A Theory of Copyright's Derivative Right and Related Doctrines, MinN. L. REV. (forthcoming 2005) (manuscript at 34-36) (explaining why a "super-copyright” regime would be problematic). The possibility that the government might auction patent rights has received only two footnotes plus one sentence worth of attention in the literature. See infra Part I.A-B.

8 The Patent and Trademark Office already defines various invention classifications through the U.S. Patent Classification System. See, e.g., http://www.uspto.gov/go/classification/ (last visited July 12, 2005); see also 35 U.S.C. § 9 (authorizing the classification system). A single patent conceivably might be classified in several classifications, however, and if rights to a particular subclass were to be auctioned, more attention might need to be paid to careful definition of the scope of the subclass.

${ }^{9}$ Edmund W. Kitch, The Nature and Function of the Patent System, 20 J.L. \& EcON. 265 (1977).

${ }^{10} \mathrm{Id}$. at 267 (emphasizing the issues of patent scope and early patent application and issuance).

${ }^{11}$ For example, Robert Merges and Richard Nelson conclude:

Public policy, including patent law, ought to encourage inventive rivalry, and not hinder it. As the 'race to invent' models show, a rivalrous structure surely has its inefficiencies. But such a structure does tend to generate rapid technological progress and seems a much better social bet than a regime where any one or a few organizations control the development of any given technology.

Robert P. Merges \& Richard R. Nelson, On the Complex Economics of Patent Scope, 90 CoLuM. L. REV. 839, 908 (1990); see also id. at 877 ("[W]e have little faith in the imagination and willingness of a 'prospect' holder to develop that prospect as energetically or creatively as she would when engaged in competition.”). Mark Lemley insists that the empirical claim "that an initial inventor is better suited to control research than the market is fundamentally an empirical one" and that the empirical claims "has been tested and found wanting." Mark Lemley, Ex Ante Versus Ex Post Justifications for Intellectual Property, 71 U. 
decisionmaking on which projects to pursue, ${ }^{12}$ but proponents identify countervailing considerations. ${ }^{13}$ If patents are granted sufficiently early, they might lessen the inefficiency associated with patent races, ${ }^{14}$ as the certainty of being able to capitalize on any successful research might lead an auction winner to invest more and earlier in research and development. ${ }^{15}$ Similarly, broader patents reduce inefficiencies associated with “inventing around.”16

Precisely the same arguments may be made about auctions, which will tend, for better or worse, to centralize in the winner of the patent the power to coordinate invention. The possibility of auctioning intellectual property rights may thus be seen as an extreme version of prospect theory. This Article will not attempt a resolution of the difficult empirical questions about the relative virtues of competition and centralized control in the inventive process, let alone announce a verdict on prospect theory. For two reasons, however, the prospect approach is strengthened when it is realized through a well-run auction rather than through some version of the existing patent system. First, an auction system can allow for prospects that are granted earlier and more broadly than is feasible in the existing patent system. ${ }^{17}$ An auction system can thus increase the benefits of a prospect approach in encouraging early invention and avoiding duplicative invention. For example, one criticism of the prospect approach is that it encourages

CHI. L. REv. 129, 141 (2004). The ultimate question, however, is not simply whether an "initial inventor" will better control research than competitive firms, but whether an early granting of an intellectual property right may lead to earlier invention. There are strong theoretical reasons for believing that the answer is affirmative. See infra Part I.C (considering Professor Duffy's demonstration of how the reduction in competition associated with patent races may accelerate innovation).

12 See Tim Wu, Intellectual Property, Innovation, and Decision Architectures, VA. L. REV. (forthcoming 2005) (arguing that patents may harm innovation by centralizing decisionmaking, but acknowledging that centralized information may be useful in some information contexts).

${ }^{13}$ For an argument that centralized decisionmaking may reduce costs associated with duplication and delay, see Patrick Bolton \& Joseph Farrell, Decentralization, Duplication, and Delay, 98 J. PoL. Econ. 803 (1990). Wu disputes the relevance of Bolton and Farrell's analysis for intellectual property, arguing that "the relative quickness of centralized decision-making structures ... seems less important in the intellectual property context.” Wu, supra note 12 (manuscript at 5 n.13). But in innovation as in tax, timing is everything, since any feasible and potentially valuable invention presumably will be created someday. Bolton and Farrell note that if two firms have equal costs, they may enter into what eventually will be a natural monopoly market simultaneously, creating duplication, and if both have high costs, they may both wait, creating delay. Bolton \& Farrell, supra, at 805. These problems exist as well in the intellectual property context, when two potential inventors have roughly equal chances of winning a patent.

${ }^{14}$ For overviews of the economics of patent races, see JEAN TIROLE, THE THEORY OF Industrial OrganiZATION 394-414 (1988); and Partha Dasgupta \& Joseph Stiglitz, Uncertainty, Industrial Structure, and the Speed of R\&D, 11 BELL J. ECON. 1 (1980).

15 See infra Part II.A.2.a.

${ }^{16}$ The Federal Circuit has embraced inventing around, insisting that it "is the stuff of which competition is made." State Indus., Inc. v. A.O. Smith Corp., 751 F.2d 1226, 1236 (Fed. Cir. 1985); see also Paul N. Katz \& Robert R. Riddle, Designing Around a United States Patent, 45 S. Tex. L. Rev. 647, 649 (2004) (endorsing the Federal Circuit conclusion and claiming that designing around is "one of the ways in which the patent system works to the advantage of the public"). Some commentators, however, have emphasized the inefficiencies associated with inventing around. See, e.g., Louis Kaplow, The Patent-Antitrust Intersection: A Reappraisal, 97 HARV. L. REV. 1813, 1869 (1984) (recognizing that if the new invention adds no functionality, the expense of creating it is wasted and the reward function of the patent system is dampened).

${ }^{17}$ See infra text accompanying notes 108-109. 
excessive competition in the race to a patent, ${ }^{18}$ but an early auction can eliminate this inefficiency. Second, an auction system can be designed to avoid some of the potentially negative consequences of the prospect approach. We will see that auctions can be designed to reduce a patentee's power over price and thus deadweight loss, or to counteract a patentee's incentive to develop only some of the technologies within the scope of a patent.

Even so, the patent system probably is superior to an auction system, at least as a general matter. An auction might work well only if it is well run, but there are formidable obstacles to efficient governmental execution of patent auctions. Ultimately, this Article seeks only to make uneasy the conclusion that the existing system granting rights to successful inventors necessarily dominates an auction approach. A substantial literature considers whether the patent system is superior to the alternative of a reward system, ${ }^{19}$ but the literature ignores that there is a third possible strategy for encouraging inventive activity, the granting of exclusive rights through auctions. This Article will seek to describe the range of ways in which patent auctions might work. Plainly, this analysis is of greater theoretical than practical interest. The auction idea has heuristic value as an idealization of the prospect approach and serves to emphasize more broadly how bidding and racing can be substitute methods for awarding property rights. With this background, the Article seeks its practical payoff by describing much more modest auction proposals.

The more theoretical portion of this Article extends a recent analysis by John Duffy, ${ }^{20}$ though differing on some key points. ${ }^{21}$ That article, while not considering the possibility of actual

\footnotetext{
18 See Donald G. McFetridge \& Douglas A. Smith, Patents, Prospects, and Economic Surplus: A Comment, 23 J.L. \& Econ. 197 (1980).

${ }^{19}$ See, e.g., Michael Abramowicz, Perfecting Patent Prizes, 56 VAND. L. Rev. 115 (2003); Steve P. Calandrillo, An Economic Analysis of Property Rights in Information: Justifications and Problems of Exclusive Rights, Incentives to Generate Information, and the Alternative of a Government-Run Reward System, 9 FordHAM InTELL. Prop. MEdia \& ENT. L.J. 301 (1998); Michael Polanvyi, Patent Reform, 11 Rev. Econ. Stud. 61 (1944); Steven Shavell \& Tanguy van Ypersele, Rewards Versus Intellectual Property Rights, 44 J.L. \& ECON. 525, 537-39 (2001). Conceivably, an auction system might be combined with a reward system, in which the government sometimes might take exclusive rights it had previously granted in exchange for just compensation. The reward system would thus be invoked only once the auction system had provided sufficient incentives for an auction winner to generate (and perhaps commercialize) socially valuable inventions.

20 John F. Duffy, Rethinking the Prospect Theory of Patents, 71 U. CHI. L. REV. 439, 476-80 (2004). Some earlier commentators recognized the similarity between a patent race and an auction. See, e.g., Wolfgang Leininger, Escalation and Cooperation in Conflict Situations, 33 J. ConfliCt REsol. 231, 233 (1989) (analogizing a patent race to an "escalation" or "all pay" auction in which all auction participants must pay but only the highest bidder wins). Duffy, however, appears to be the first commentator to recognize that patent racers bid not only by committing a particular amount of money to research and development but also by deciding when to commit that money.

21 See infra Part I.C. For example, Duffy rejects the classic prospect theory position that patents should be broad, but the possibility of explicit auctions helps crystallize the benefits of broad patents. The endorsement of relatively broad patents is critical to the Article's ultimate policy proposal. See infra Part IV.B.
} 
auctions of patent rights, argues that the patent system functions in some respects like an auction, in which a patent is awarded to one of the inventors who agree to start racing earliest and thus implicitly consent to place the invention in the public domain first. The analogy highlights that a patent auction need not award a patent to the bidder who offers to make the highest cash payment to the government. Consideration of the possibility of explicit auctions enables analysis of several different approaches for selecting the winning bidder. A patent auction, for example, might award the patent to the inventor who commits the most resources to research and development, ${ }^{22}$ who accepts the shortest patent term, ${ }^{23}$ or who agrees to sell or license the patented invention for the lowest amount of money. ${ }^{24}$ A significant potential benefit of patent auctions is that prospective inventors compete to offer as much as possible to the public, rather than solely to earn as much as possible through monopoly pricing from the public. ${ }^{25}$ One reason that patent auctions may have received so little attention from scholars is that pure cash auctions appear to be little more than an inefficient tool for generating government revenue. Patent auctions may become more attractive, however, once alternative forms for auction bids are considered, and the prospect theory in general becomes more attractive, the greater the extent to which system design can overcome some of its limitations.

A significant obstacle, however, remains: No single form of auction bid can capture the social welfare that a prospective patentee expects to provide. The more the winning bidder offers in the form of a shorter patent term or a reduced price, for example, the less incentive the patentee will have to develop inventions within the patent scope. At the limit, anyone could offer a zero patent term or zero price and then do nothing to develop the patent. With a shortest patent term or lowest price auction, then, the winning bidder would need to be required also to make some commitment to developing the patented product. This might come in the form of a payment to the government, or payment into a fund to be used only for future development costs. More

\footnotetext{
22 See infra Part III.A.

${ }^{23}$ See infra Part III.B.1 (considering and comparing patent term auctions and pure cash auctions).

${ }^{24}$ Even where a patent might cover numerous products or services, a patent auction could approximate the low price approach by awarding the patent to the bidder who agrees to accept the lowest fraction of typical patent damages, compulsory license rates, or regulated prices. See infra text accompanying notes 181-184.

${ }^{25}$ To the extent that the existing patent system functions as an implicit auction, it too may have this feature, as the winning inventors are those who offer the shortest effective patent terms. See infra Part I.C. (discussing Professor Duffy's insight). Explicit price auctions, however, may be more efficient, because the last increment of monopoly pricing tends to be the most socially costly. See infra text accompanying notes 169-175 (discussing the implications of an analysis by Ian Ayres and Paul Klemperer). A slight price concession for a long patent term is likely more efficient than a large price concession for a short term, if the two provide equal value to the bidders.
} 
complex auction designs might require the government to choose the bidder who offers the public the best overall package, considering variables such as patent term, price, payment to the government, and commitment of money to a development fund. ${ }^{26}$ There is no obvious formula for the government to use in comparing bid packages, however. ${ }^{27}$ Whether the government selects how it will weigh different components of a bid in advance or evaluates bid packages case-by-case, it risks placing excessive weight on some goals of patent law (such as encouraging development of patented inventions) at the expense of others (such as limiting deadweight loss). This tradeoff between static and dynamic efficiency is familiar to patent scholarship, ${ }^{28}$ though in the case of auctions, the question is whether there will be enough incentives to invent after a patent is issued.

The analysis proceeds as follows: Part I reviews past proposals that, in passing, have noted the possibility of auctioning patent rights, as well as Duffy’s proposal and another proposal integrating an auction mechanism into the patent system. A principal purpose of this Part is to identify assumptions relaxation of which might strengthen the case for an auction system. Part II then evaluates patent auctions, focusing on cash auctions for blocking rights in particular fields. The principal benefit of a patent auction is that it can allow for broader patent rights than are feasible in the existing patent system. By reducing inefficient duplication, a patent auction can increase a property right holder's incentives to engage in inventive activity. Part III considers the design of patent auctions. It shows that incentives to engage in inventive activity also can be promoted by an auction design specifically geared to that goal, and that patent auctions also might be designed to minimize concerns about deadweight loss. Finally, Part IV considers alternative proposals for implementing patent auctions and for overcoming the difficulties associated with governmental selection of rights to auction. One proposal would be to have auctions that reduce the number of patent racers in a technological field, but do not give a single party exclusive rights. The second proposal is for patent scope auctions, in which a patentee

\footnotetext{
${ }^{26}$ See infra Part IV.A.1.

27 The Article will consider how the government might seek to harness private information in comparing bids. If such approaches could be perfected, the optimal approach might not be for the government to hold patent auctions, but for the government to hold auctions that would give bidders incentives to define the optimal structure of patent law in particular technological fields. See infra Part IV.A.2.

${ }^{28}$ See, e.g., William D. Nordhaus, Invention, Growth, and Welfare: A Theoretical Treatment of Technological CHANGE 76 (1969) ("[A] longer [patent] life increases invention and thus gives on balance a larger amount of output for a given level of inputs. [But] a longer life means that the monopoly on information lasts longer and thus there are more losses from inefficiencies associated with monopoly.”).
} 


\section{PATENT RACES VS. PATENT AUCTIONS}

could call for an auction of expanded patent scope, but could win the auction only by substantially outbidding competitors. With a sufficiently high markup demanded, a patentee will have incentives to call for patent scope auctions only in situations in which concerns about inefficient duplication of resources are particularly salient, thus making patent auctions socially beneficial.

In the end, the most important practical lesson from the theoretical explanation of patent auctions is that the analysis reinforces the classical prospect theory position that there might be benefits from patents with considerably broader scope than is now possible with the existing patent system. The literature on patent scope considers only relatively marginal policy choices, such as those presented by the doctrine of equivalents. ${ }^{29}$ Administrative convenience demands that patents hew closely to what the inventor has already achieved, but theory suggests that patent scope should depend on analysis of alternative inventions targeting the same consumer need, in particular the additional benefits that these inventions would provide and the cost of developing them. Patent scope auctions provide one mechanism for selectively broadening patent scope in cases in which this analysis suggests that broad scope would be more efficient. Admittedly, other hypothetical approaches might be more politically palatable, because the patent system, indeed the legal system generally, does not currently integrate auction mechanisms. Perhaps the ultimate goal of this Article, however, is to make the possibility of integrating auction and other mechanisms into the patent system less alien and to open a conversation that might lead to genuinely modest proposals for using market mechanisms to incorporate information not easily accessible to governmental officials in a patent office.

\section{A BRIEF INTELLECTUAL History OF PATENT AUCTIONS}

This Part will provide an intellectual history of patent auctions. This history will be brief for two reasons. First, no one has ever considered in more than a footnote whether it might be useful to auction intellectual property rights rather than granting rights to their creators. Those who casually imagined auctions presumably envisioned only auctions for particular innovations, rather than auctions for technological fields. Because it is difficult to auction specific innovations

\footnotetext{
${ }^{29}$ See infra note 105 and accompanying text (discussing the doctrine of equivalents); see also Douglas Lichtman, Rethinking Prosecution History Estoppel, 71 U. CHI. L. REV. 151 (2004) (providing an analysis of the doctrine of equivalents and the related doctrine of prosecution history estoppel).
} 
before they are developed, no one has viewed the possibility of an auction as anything other than a heuristic device. There is thus little history to recount. Second, my purpose is analytical rather than historical. Instead of describing each of the four articles that constitute the intellectual history, I will offer only the barest summary and then identify a particular explicit or implicit assumption about the inventive process that underlies the article's position on patent auctions. Relaxing these assumptions entails a recognition that because patents are limited in both time and technology, inventors can only partly internalize the benefits of research and development and may thus have inadequate incentives to research and develop patented products. Patent auctions may be able to provide for broader property rights and more robust innovation incentives, though potentially at the cost of greater deadweight loss.

\section{A. Barzel on the Optimal Timing of Innovations}

In Optimal Timing of Innovations, ${ }^{30}$ Yoram Barzel argued that sometimes innovations may be produced inefficiently early. Assume that there is some cost to a particular innovation. Some private party will decide to produce the innovation once the net present value of the innovation just exceeds zero, ${ }^{31}$ i.e. once the rents that the private party can obtain from the innovation will be just enough to offset the cost of producing it. The inventor will not wait until later than that, because if the inventor does so, somebody else will have an economic incentive to produce the innovation first. If the inventor could prevent others from producing the innovation in the meantime, however, the inventor would have an incentive to wait. Assuming that the cost of the innovation is constant and the demand for it will grow over time, ${ }^{32}$ the inventor would be better off delaying invention, and earning a normal rate of return on the funds that would be used for the innovation in the interim. Intuitively, if there is some moment of invention that would produce a positive rent for an inventor, then inventors will dissipate that rent by inventing earlier, because no inventor owns a property right in determining when to invent.

In a footnote, Barzel suggested that this inefficiency could be overcome by granting monopoly rights on innovations, for example through an auction. ${ }^{33}$ The conclusion that invention

\footnotetext{
30 Yoram Barzel, Optimal Timing of Innovations, 50 REV. ECON. \& STAT. 348 (1968).

${ }^{31} I d$. at 351 . Zero is used here in the conventional economic sense of corresponding to a normal rate of return.

${ }^{32}$ Id. at 349 (assumptions 1 and 3).

${ }^{33}$ Id. at $352 \mathrm{n} .11$ ("A conceptual way to overcome this kind of misallocation is by granting (or by auctioning) monopoly rights on potential innovations before resources are committed to the innovating activity.”).
} 
would be too early from a social perspective in the absence of such a grant, however, depended on an assumption that Barzel made explicitly, ${ }^{34}$ but acknowledged was "quite strong" 35 : that the inventor is able to appropriate the full social benefits of the invention. When society receives benefits from an invention that do not accrue to the inventor, invention might occur too late, and so, Barzel recognized, in the absence of property rights, the net effect of these opposing forces was indeterminate. ${ }^{36}$ Barzel's argument thus identifies a countervailing consideration to what he acknowledged as the conventional wisdom that there generally are insufficient incentives to innovate. ${ }^{37}$ The economic literature on intellectual property, however, suggests that this conventional wisdom is powerful, and that inventive activity generally produces significant spillovers that patentees cannot capture. ${ }^{38}$ That suggests that when a patent leads to delay in completion of inventive activity, that delay should count as a social cost, rather than as a social benefit.

This might at first appear to undermine Barzel's footnote suggestion for granting rights through auctions, but in fact it might suggest a benefit of auctions. In general, spillovers and other forms of positive externalities exist when property rights are ill-defined. ${ }^{39}$ Until a patent is issued, no one has a property right in the underlying invention, and inventors will be able to capture only a portion of the value of their efforts, for example if they are fortunate enough to win the patent race. As a result, the total level of effort will be suboptimal. Providing property rights at an earlier stage, for example through an auction, could allow inventors to capture a greater proportion of the social benefits that their inventive activity creates, leading to greater investment in research and development. Certainly this would be true if the auctioned property right is granted sufficiently early and with sufficiently broad scope to eliminate spillovers.

\footnotetext{
${ }^{34}$ Id. (assumption 4).

${ }^{35}$ Id. at 350.

${ }^{36}$ Id. at 355 tbl.2.

${ }^{37}$ This is clear in the first sentence of his piece. See id. at 348 ("It is widely recognized that when innovators are unable to realize the full benefits generated by their innovations the profit motive may not provide an incentive strong enough for them to innovate at the socially optimal rate.”).

${ }^{38}$ For attempts to measure the extent of spillovers, see Timothy F. Bresnahan, Measuring the Spillovers from Technical Advance: Mainframe Computers in Financial Services, 76 Am. ECON. Rev. 742, 753 (1986); Edwin Mansfield et al., Imitation Costs and Patents: An Empirical Study, 91 Econ. J. 907 (1981); and M. Ishaq Nadiri, Innovations and Technological Spillovers (Nat'l Bureau of Econ. Research, Working Paper No. 4423, 1993).

${ }^{39}$ See, e.g., Janusz A. Ordover, Economic Foundations and Considerations in Protecting Industrial and Intellectual Property, 53 ANTITRUST L.J. 503, 509 (1985) (noting that governmental research subsidies may be needed when stringent property rights are not available to reduce the extent of inventive spillovers).
} 
Auctions thus might be justifiable, but the social calculus may be the exact opposite of what Barzel's analysis would appear to suggest. Auctions may be justified because they make delay less rather than more likely. Auctions will be valuable to the extent that they reduce spillovers and thus increase the overall level of inventive activity within the scope of the property right, but there is a danger that because some spillovers will still exist, property rights might lead to inefficient delays in inventive activity. The case for auctions will thus be strongest, the greater the extent to which an auction helps consolidate property rights that would remain fragmented in a traditional patent system. The patent system can leave property rights fragmented across two dimensions: time, because the patent term is limited; and technology space, because a particular patent in the existing system will ordinarily protect only one particular means to solving a given problem, yet might provide information helpful to other researchers and investors in a technology area. Parts I.B and I.C will use other works on patent auctions to consider these dimensions, respectively, before turning in Part I.D to a concern that broad property rights inevitably would create increases in consumer prices and thus deadweight loss.

\section{B. Kitch on Prospect Theory}

Although Barzel's footnote proposal for auctioning innovation rights was undeveloped, Edmund Kitch seized upon it in announcing his seminal prospect theory of patent law, ${ }^{40}$ acknowledging that his "ideas first crystallized in response to Barzel’s essay." ${ }^{41}$ Barzel, Kitch wrote, recognized that a claim system could prevent inefficiently rapid depletion of the common pool of technological information. "What Barzel did not realize,” Kitch wrote, “is that a patent system can be such a claim system and, indeed, that it is a more sensible system than an auction system would be.” 43 Kitch backed up the claim that the patent system would be "more sensible" with only a brief single footnote: "Because the patent creates private incentives for the identification and definition of claims and puts the claim identification and the claim development process in the same hands." ${ }^{44}$ This must be among the most perceptive phrases in

\footnotetext{
${ }^{40}$ Kitch, supra note 9.

${ }^{41}$ Id. at 265.

${ }^{42} \mathrm{Id}$.

43 Id. at 265-66.

${ }^{44} \mathrm{Id}$. at 266 n. 4.
} 
law and economics, though we will see that the comparison between an auction system and a patent prospect system is more complicated than Kitch allowed.

The patent system, Kitch argued, not only provides useful ex ante incentives, but also provides benefits ex post. Among other virtues, the system "puts the patent owner in a position to coordinate the search for technological and market enhancements of the patent's value," 45 "lowers the cost for the owner of technological information of contracting with other firms possessing complementary information and resources," ${ }^{46}$ and "reduce[es] the amount of duplicative investment in innovation." ${ }^{47}$ Kitch's article remains arguably the most important and the most controversial in patent theory. A principal criticism is that the possibility of prospect patents will simply shift duplicative investment to the pre-patent stage. ${ }^{48}$ Auctions provide a potential antidote, because there is no sense in racing to invent if exclusive rights are to be (or have been) distributed through auction. Auctions also may be responsive to a second criticism, that even after patents are granted inventors will compete to improve patents, ${ }^{49}$ if the property rights granted through auction are sufficiently broad. Thus, while Kitch's identification of ex post benefits to property rights advance the case for auctions, the limits of a patent prospect's approach to providing those benefits might strengthen the case for auctions still more.

Despite the great deal of attention that Kitch's analysis has received, there is one assumption in his analysis that commentators appear to have ignored, and relaxing this assumption can point both to an unappreciated benefit of the auction approach and to a subtle risk. Kitch acknowledges that "[o]peration of the prospect function requires that the owner have most of the present value of the invention for the investment period." ${ }^{50}$ Kitch reasons that given a five-year investment cycle, the then-seventeen-year term should "give the owner a large part of the present value." ${ }^{51}$ But if the inventor does not begin development right away, less of the patent term would be left. Indeed, perhaps so little of the patent term will be remaining that the inventor might well not develop the invention at all.

\footnotetext{
${ }^{45}$ Id. at 276.

${ }^{46} I d$. at 277.

${ }^{47}$ Id. at 278.

${ }^{48}$ McFetridge \& Smith, supra note 18.

${ }^{49}$ See, e.g., Roger L. Beck, The Prospect Theory of the Patent System and Unproductive Competition, 5 RESEARCH L. \& ECON. 193, 194 (1983).

${ }^{50} I d$. at 285.

${ }^{51}$ Id.
} 
This might seem to be an implausible concern, for why would the inventor not begin development right away? Barzel's analysis, however, provides a partial answer: It might be in the interest of the patentee, even if not in the social interest, to delay inventive activity. Even so, why would an inventor have gone through the trouble to acquire a patent, only to later abandon it? The simple answer is that the receipt of a patent provides the patentee with an option to develop and commercialize the patent, but options often turn out to be not worth exercising. ${ }^{52}$ Kitch might implicitly be assuming that the benefits and costs of commercializing a patent are predictable in advance, but market conditions might change after a patent is issued. It thus sometimes will make sense to patent an invention that seems likely to be worth commercializing only in the last years of a patent term, or even that seems unlikely to be worth commercializing at all in the patent term, if there is some chance that market conditions will in fact make commercialization worthwhile.

The danger of nondevelopment thus accentuates that property rights in inventions are fragmented over time, with the patentee owning the right only for a period of time and the public owning the right in common thereafter. Conceivably, an auction approach could reduce the risk of patent nondevelopment by allowing for longer patent terms. Longer terms would reduce the extent of spillovers, providing inventors greater incentive to invent and to perform research and development within the scope of the patent right. A tradeoff thus inheres in adoption of auctions: If auctions provide long patent terms, incentives to invest in research and development increase, but so too does the social cost of monopoly pricing, deadweight loss. ${ }^{53}$ Because auctions can be structured in different ways, ${ }^{54}$ this presents not only a tradeoff inherent in switching to an auction system from a patent system, but also a tradeoff in auction design. If the auctioned patent term is sufficiently short, deadweight loss will fall, but the remaining spillovers might be so great that the auctioned right will increase the extent of inefficient delay and lower social welfare.

\section{Duffy on Demsetzian Auctions}

Though he too does not consider the possibility that uncertainty about the benefits and costs of developing the invention might end up resulting in effective patent terms so short that

\footnotetext{
52 For a more detailed version of this argument, see Michael Abramowicz, The Problem of Patent Underdevelopment (2005) (unpublished manuscript, on file with author).

53 See generally NoRDHAUS, supra note 28, at 76 (exploring this tradeoff).

${ }^{54}$ See infra Part IV.
} 
inventors fail to develop inventions, Professor Duffy, in Rethinking the Prospect Theory of Patents, ${ }^{55}$ does recognize the centrality of patent expiration to an assessment of the prospect system. Indeed, Duffy argues that a consideration of patent expiration answers a central criticism of the prospect theory, ${ }^{56}$ that prospect patents cannot eliminate inefficient duplication of effort, because they instead will tend only to intensify races to obtain patents in the first place. ${ }^{57}$ If patents produce positive rents, those rents will be dissipated away by some form of competition. Duffy's observation is that competition in invention is not the only other means of dissipating rents. Rents also can be dissipated by earlier patenting. Such early patenting, Duffy maintains, is necessarily efficient, because it will result in the invention being placed in the public domain sooner rather than later. ${ }^{58}$

Duffy analogizes the patent system to a Demsetzian auction. ${ }^{59}$ Harold Demsetz argued that instead of regulating the price that a utility natural monopoly could charge, the government could simply hold an auction for the right to serve as the monopolist, with the winner offering the best package of price and quality. ${ }^{60}$ The competition among potential utilities would result in the winning bidder offering service relatively close to marginal cost, thus reducing deadweight loss. ${ }^{61}$ Similarly, potential patentees compete by offering to place the invention in the public domain sooner, thus also reducing deadweight loss. Because the prospect system by definition grants patents at a relatively early stage, potential patentees will begin racing early enough so

\footnotetext{
${ }^{55}$ Duffy, supra note 20.

${ }^{56}$ Duffy's analysis also helped answer the second major criticism of the prospect theory, that our patent system is not a prospect system that genuinely gives a patentee the power to control innovation, because it allows improvers to receive patents within the claims of the granted patent. Id. at $443 \mathrm{n} .22$ (citing sources making this objection); see supra note 49 and accompanying text (noting this objection). A true prospect system that did prevent improvements, moreover, might stifle innovation. Duffy notes that the power of a prospect patent holder to block holders of improvement patents from using their inventions provides some control over invention. Id. at 448. More importantly, the inevitability of patent expiration provides prospect patent holders a continuing incentive to compete to obtain patentable improvements. Id. Thus, even under a prospect system, inventors will compete in time to improve earlier, with the result that improvements too end up in the public domain earlier.

${ }^{57}$ McFetridge \& Smith, supra note 18. Later commentators suggested that the patent system might be seen as a mechanism that seeks to reduce the sum of the inefficiencies associated with patent races and competitive development of patented inventions. See Mark F. Grady \& Jay I. Alexander, Patent Law and Rent Dissipation, 78 VA. L. ReV. 305, 317 (1992) (“[A] full accounting of the effects of the patent system must balance the savings in reduced follow-on investment against the losses from accelerated pioneering investment.”).

${ }^{58}$ Duffy, supra note 20, at 443-44, 464-75.

59 Id. at $475-80$.

${ }^{60}$ Harold Demsetz, Why Regulate Utilities?, 11 J.L. \& ECON. 55, 63 (1968).

61 Demsetz's theory that natural monopolies does not necessarily depend on the government holding a centralized auction, though a centralized auction in effect usefully facilitates collusion among buyers. Id. at 57-58 (providing a simple example involving a natural monopoly in production of license plates).
} 
that profits during the effective patent term are just enough to cover the costs of racing. ${ }^{62}$ In effect, the patent system is a shortest-patent-term auction, with the patent awarded to one of the inventors who are willing to attempt the invention first. ${ }^{63}$ The patent system differs from a pure shortest-patent-term auction only because the patent system does require some level of accomplishment to obtain a patent prospect, and thus there might be a race to determine who accomplishes the invention and thus receives the patent.

Duffy points out that because the issuance of a prospect patent ends the race, it will reduce duplicative efforts. The result is that the race will start earlier than it would have otherwise. Because inventors can always engage in other activities-other patent races or other work altogether - they will not begin any given patent race until they expect to profit from entering. Entry should become more attractive over time, for example because the cost of producing a particular invention falls with general technological development or because society's demand for the invention rises. But each inventor considering when to enter must contemplate not only the cost of completing the invention and the benefit of the patent, but also the possible cost of losing the patent race. This cost will be less if the prospect is granted early, and so a prospect approach will lead inventors to start racing earlier than they would have if they expected that all racers would incur costs after the time that a prospect patent is issued. ${ }^{64}$ The combination of this earlier racing and the earlier award of the patent means that the invention will be committed to the public domain earlier as well. This point poses a significant problem for commentators who believe that the competition the patent system creates is generally efficiency-enhancing. ${ }^{65}$ Competition might well provide extra motivation to race participants during the race, but the race might start later, the longer potential inventors are allowed to remain in the race after it begins.

An assumption of Duffy's model is that once one racer obtains a patent, the patent race ends. The assumption might be problematic, however, because different racers might be working on different means to the same goal, and the prospect patent might not be broad enough to cover all of the means. Even after the prospect patent issues, other inventors might continue their

\footnotetext{
62 Duffy, supra note 20, at 469-75 (offering a model in which inventors race to obtain a patent).

63 There may be some randomness in who obtains the patent, because an attempt to invent may or may not be successful. Nonetheless, this does not change the fundamental conclusions of Duffy's analysis. Id. at 480-82.

${ }^{64}$ Id. at $470-72$.

${ }^{65}$ See supra note 11 (noting commentators' failure to recognize the point later made by Duffy).
} 
efforts, now seeking to invent around the original patent and perhaps obtain their own patents, thus allowing them to sell products or services that will be substitutes for those of the original patentee. ${ }^{66}$ Because Duffy ignores the possibility that patent races might continue after a patent initially issues, he rejects the standard recommendation of prospect theory that patents should be broad. ${ }^{67}$ Once the possibility of inventing around is considered, however, Duffy's broader analysis supports broad patents. Just as the implicit patent auction dissipates rents associated with patent auctions, so too can such auctions dissipate rents associated with inventing around, but only if the auctioned rights are sufficiently broad.

Although Duffy's model is an auction model, he too never considers the possibility of issuing intellectual property rights through an explicit auction. Initially, his analysis might appear to suggest that explicit patent auctions are unnecessary, because implicit patent auctions already exist. The possibility of inventing around, however, suggests a significant benefit of patent auctions relative to the existing patent system. It is relatively straightforward in a patent auction to define rights broadly; indeed, explicit auctions will almost necessarily encompass fields of technology rather than individual inventions. It is far more challenging for a patent system, which grants rights based on inventive achievement, to grant rights beyond what inventors have actually achieved. ${ }^{68}$ Broad patents reduce spillovers, and auctions can provide breadth in the technology dimension. Auctions providing such patents can thus increase prospective inventors’ confidence that they will be able to recoup the benefits of the research and development that they fund.

\section{Bar-Gill and Parchomovsky on Auctioning Ideas}

Although two important papers have considered the possibility that completed patents might be auctioned, ${ }^{69}$ no one has suggested that an auction might substitute for the patent system.

\footnotetext{
${ }^{66}$ Kitch recognized the possible inefficiency of inventing around, but thought prospects might help patentees enter into agreements with potential competitors that would help "forestall the wasteful investment.” Kitch, supra note 9, at 279. Kitch, however, acknowledged that "the patent holder cannot offer discounts to everyone who threatens to look for a substitute." $I d$.

${ }^{67}$ Duffy, supra note 20, at 499-500.

${ }^{68}$ See infra Part II.A.1.

69 See Michael Kremer, Patent Buyouts: A Mechanism for Encouraging Innovation, 113 Q.J. EcoN. 1137 (1998) (suggesting an auction that would be consummated only some of the time, with the information from the bids used the rest of the time to buy out the patentee and place the patent into the public domain); Ian Ayres \& Paul Klemperer, Limiting Patentees’ Market Power Without Reducing Innovation Incentives: The Perverse Benefits of Uncertainty and Non-Injunctive Remedies, 97 MicH. L. REV. 985, 1031-32 (1999) (suggesting a "duopoly auction" in which the patentee would receive the revenues from an auction for a complete license to the patent, as a way of ensuring some degree of competition within the patent system).
} 
One recent paper, however, comes close to offering such a proposal. In A Marketplace for Ideas, Oren Bar-Gill and Gideon Parchomovsky suggest a two-tier patent system, in which someone who generates and successfully registers an idea would receive the proceeds from an auction of the right to further develop and patent the idea. ${ }^{70}$ The criteria for registering an idea would be similar to the existing standards for patentability, ${ }^{71}$ so properly conceived, the proposal is more akin to the two proposals for auctioning completed patents than to a suggestion that auctions might serve as alternatives to the patent system. Nonetheless, ideas conceivably might be developed in multiple ways, ${ }^{72}$ and so an idea registration might be considerably broader than a typical patented invention, making the proposal somewhat akin the patent auctions considered here. Moreover, the proposal furnishes a clever means of encouraging innovation, and analysis of it highlights a common, but potentially problematic, assumption about the patent process.

Under Bar-Gill and Parchomovsky’s proposal, the idea would fall into the public domain either if no one bid on the right to develop the patent, ${ }^{73}$ or if the auction winner "failed to produce a patent or product within a given time period, say two years." ${ }^{\text {,4 }}$ The proposal reflects a balance between two concerns. The first is that absent any protection, there will be underproduction of ideas. ${ }^{75}$ The second is that full-fledged patent protection for ideas creates a

\footnotetext{
70 Oren Bar-Gill \& Gideon Parchomovsky, A Marketplace for Ideas?, TEX. L. REV. (forthcoming 2006). Bar-Gill and Parchomovsky also suggested that under certain circumstances, it might be optimal instead to allow anyone to develop the idea, subject to a liability rule compulsory license regime. See id. at 18-23.

${ }^{71}$ For example, idea registrants would have to satisfy the traditional criteria of usefulness, novelty, and nonobviousness. Id. at 31. The inventors would also have to demonstrate "developability," i.e. that the invention "constitutes a material contribution to the innovative process," and does not fit within the category of "fanciful ideas (i.e., those deemed undevelopable by a person skilled in the technological field to which the idea belongs).” Id. at 32. Although there is substantial ambiguity about the developability requirement, Bar-Gill and Parchomovsky make clear that it is not a high bar. See id. ("Importantly, developability is more lenient than implementability. Ideas, as opposed to patents, need not be readily implementable. By its very nature, an idea lacks the detail required for implementation.”).

${ }^{72}$ Id. at 25 (considering an alternative auction design in which "developers would not bid on ideas in their entirety, but rather on individual applications of ideas they wished to pursue").

73 Id. at 23-24. Bar-Gill and Parchomovsky "believe that a relatively small percentage of ideas would be picked up by developers.” Id. at 24. This conclusion, however, depends on the additional stipulation that there would be a rule requiring some minimum bids. Id. at 24 n.71. Bar-Gill and Parchomovsky suggest that this will prevent "idea conceivers [from] bidding token amounts on their own ideas just to prevent them from falling into the public domain.” Id. The problem, however, is more complicated. Someone might bid a relatively low bid to obtain the option to develop, even recognizing the small likelihood that the option will turn out to be worth exercising. See supra Part I.C. Thus, some care must be taken in setting the appropriate level of the minimum bid.

${ }^{74}$ Id. at 27. Bar-Gill and Parchomovsky do not explicitly say that failure to develop would lead to development rights being placed in the public domain. This is the most natural reading of their proposal, but they say only that the entitlement would be "strip[ped] away." Id. In theory, the entitlement could be reauctioned if development did not occur.

${ }^{75}$ Id. at 10-13. Bar-Gill and Parchomovsky argue that the possibility of entering nondisclosure agreements does not solve the problem, because of the paradox that the best legal developers will not want to risk signing nondisclosure agreements until they know about the invention. Id. at 9.
} 
bilateral monopoly between the idea holder and any potential developer that might deter the developer from using the idea. ${ }^{76}$ The provision of protection responds clearly to the first concern, and the mandatory auction is intended to respond to the second.

Bar-Gill and Parchomovsky claim that the auction is superior to a property rule regime, under which "the idea conceiver must engage in costly negotiations with a potentially large number of developers.”77 Under a property rule regime, however, an idea registrant would voluntarily auction a patent if an auction appeared likely to generate greater proceeds than individualized negotiations. ${ }^{78}$ The best defense of the mandatory auction proposal might be that an idea registrant has an inefficient incentive to choose relatively high transactions costs approaches of controlling the asset. The idea registrant will be indifferent between wasting a dollar of potential surplus in bargaining and simply giving that dollar to the idea developer. If an auction genuinely economizes on transactions costs, ${ }^{79}$ then it might offset this inefficiency of idea patents relative to a world in which ideas are still produced yet remain in the public domain.

Even if mandatory auctions did not improve efficiency, Bar-Gill and Parchomovsky might defend their proposal, relative to a world in which all ideas receive ordinary patents protected by a property rule, by noting that this proposal will place more patents in the public domain. At least some ideas will fall into the public domain because no one bids to develop them, and others because the high bidder fails to develop them. The prospect of a rule demanding development is intriguing, because it might counter a danger that we have already noted, that the anticipation of patent expiration might lead patent owners not to develop their patents. ${ }^{80}$ Their approach is a stronger response to the risk of nondevelopment than the European approach of allowing compulsory licenses when a patentee fails to develop an invention. ${ }^{81}$ Even if such a rule

\footnotetext{
${ }^{76}$ Id. at $14-15$.

${ }^{77}$ Id. at 23.

${ }^{78}$ Bar-Gill and Parchomovsky concede this point but respond that "the privately optimal auction design will generally diverge from the socially optimal auction design.” Id. at $22 \mathrm{n} .66$. They do not, however, explain what the divergence would be, or justify the conclusion that a one-size-fits-all auction design chosen by the government will be more socially optimal than the design chosen by individual idea registrants.

${ }^{79}$ Sometimes individualized negotiation might be more efficient than an auction because an auction requires all participants to research the invention, even though at most one will win the right to develop it. But $c f$. Jeremy Bulow \& Paul Klemperer, Auctions Versus Negotiations, 86 Am. ECON. REv. 180 (1996) (offering a model showing that an auction generally will be more efficient than a negotiation with one less participant).

${ }^{80}$ See supra note 52 and accompanying text.

${ }^{81}$ For a discussion of the European approach to compulsory licensing, see Ronald E. Myrick, Influences Affecting the Licensing of Rights in a Unitary European Market, 4 Fordham InTELL. Prop. MEdia \& ENT. L.J. 81, 95 (1993).
} 
could be implemented, ${ }^{82}$ however, it might not be a panacea. Bar-Gill and Parchomovsky seem to assume that the placement of initially undeveloped ideas in the public domain at least promotes efficiency ex post. ${ }^{83}$ As prospect theory suggests, however, intellectual property protection might be necessary to promote the development of an idea. The rule demanding development then must be justified on the ground that it will succeed in promoting development, ${ }^{84}$ not on the ground that placing ideas that initially fall into the public domain will increase welfare.

Ultimately, the aims of the Bar-Gill and Parchomovsky proposal overlap only slightly with the aims of patent auctions as conceived in this Article. Bar-Gill and Parchomovsky are concerned about the provision of broad property rights in undeveloped ideas, but idea registrations do not appear to allow for broader scope than existing patents; a nonobvious idea like researching nanotechnology would not receive protection. Meanwhile, Bar-Gill and Parchomovsky seem willing to make broad incursions into property rights in developing ideas, in imposing both a mandatory alienation through auction requirement and a requirement that ideas be immediately be developed. The net effect of their proposal might well be to increase spillovers and thus to decrease research and development. The proposal might still be justified, for example if the bilateral monopoly problem is sufficiently severe, but that concern is quite different from the one animating both prospect theory and this Article.

\footnotetext{
82 Bar-Gill and Parchomovsky recognize the difficulty of enforcing this approach. Id. (“[V]erifying whether the development requirement has been satisfied might be costly, perhaps prohibitively so.”). One problem is what should count as a patent or product sufficient to avoid the invention being placed in the public domain. A firm might produce a useless patent or product simply to avoid losing patent rights. That would not only be wasteful, but also would evade the Bar-Gill and Parchomovsky rule, which does not require continued development after a patent or product is initially produced.

${ }^{83}$ Others make similar assumptions. For example, Mark Lemley argues that "once an intellectual property right expires, many companies can compete to make the good, and they will do so only so long as they can manufacture and distribute it for less money than people will pay to buy it." Lemley, supra note 11, at 136. Professor Lemley recognizes the counterargument that some form of intellectual property right may be necessary to provide "adequate incentives to improve on an existing work.” Id. at 138. He responds that in these cases, the proper response should be to provide intellectual property rights to the improver. Id. at 139. Patents, however, may need to be developed in ways that, at least under current doctrine, are nonpatentable. See Abramowicz, supra note 52, at 33-38 (discussing development activities that do not themselves entitle developers to additional intellectual property protection). It is not easy to see, for example, even how a hypothetical intellectual property regime would provide a reward to someone who markets a product without giving some right over the product itself. In a world in which some development and improvement of patented technologies does not receive the benefit of independent intellectual property protection, the placement of inventions into the public domain has at least the potential to harm ex post efficiency. Indeed, Lemley concedes that there are some circumstances in which prospecting rights may be justified. See Lemley, supra note 11, at 141 ("Prospect theory is needed when control over subsequent development is a necessary part of the incentive to produce the pioneering invention in the first place, as is arguably true with pharmaceuticals.”).

${ }^{84}$ Such a justification may not be straightforward. A threat to deprive a would-be developer of a patent right for failure to develop might inefficiently accelerate invention efforts. See Barzel, supra note 30 (showing that innovation may occur inefficiently early).
} 
It might seem at this point that the antidote is the reverse of what Parchomovsky and BarGill suggest, that patents should always be held in perpetuity and never placed in the public domain. But this cannot be right either. We have already seen that where a patentee cannot appropriate the full social surplus of an invention, the patentee might inefficiently delay development of that invention. ${ }^{85}$ And, of course, there are more familiar arguments against infinite patent terms. Long patent terms will lead to the deadweight costs associated with monopoly pricing, ${ }^{86}$ as well as to transactions costs associated with finding and negotiating with patentees. ${ }^{87}$ The patent term auctions that Duffy suggests cannot occur, and thus cannot dissipate rents in an efficient way, when the patent term is infinite. ${ }^{88}$ And so, along some dimension, the patent system must make some sacrifice-tolerating some deadweight loss, some nondevelopment of patents, some duplicative investment. This is inevitable. It is worth considering, however, whether a patent system based on explicit rather than implicit patent term auctions might provide for a more appropriate balance.

\section{The Uneasy Case For Patent Races OVER PATENT Auctions}

The patent system, we have seen, ${ }^{89}$ bears some resemblance to an implicit auction, in which one of the inventors who is willing to accept the shortest patent term wins the patent. This implicit auction process provides an outlet for the dissipation of rents, reducing the inefficiencies of patent races. But the process also presents a danger that the winner of a patent might have an insufficient incentive to develop it, even where development would be in the public interest. The analogy between the patent process and an auction can, of course, be taken too far. In an auction, the right is ordinarily defined before bidding, but in the patent system, the inventive activities that constitute the implicit bids end up defining the intellectual property right. And in an auction, the winner is the participant with the most attractive offer, while in the patent process the winner

\footnotetext{
${ }^{85}$ See supra Part I.A.

${ }^{86}$ See F.M. Scherer, Nordhaus’ Theory of Optimal Patent Life: A Geometric Reinterpretation, 62 AM. EcON. REV. 422,424 (1972).

87 See, e.g., William N. LANDes \& Richard A. Posner, The Economic Structure Of Intellectual Property LaW 421 (2003) (noting that transactions costs may provide a justification for narrowing intellectual property rights).

${ }^{88}$ Nonetheless, in the absence of exogenous shocks, Duffy's argument suggests that we should gradually transition to a longer and longer term. See John F. Duffy, A Minimum Optimal Patent Term (unpublished manuscript, 2004), available at http://www.ssrn.com/abstract=354282 (visited Aug. 21, 2005) (explaining that a dynamic model of invention suggests that the patent term should be no less than a particular length).

${ }^{89}$ See supra Part I.C.
} 
is the first participant to meet the requirements of patentability, even if some other inventor hypothetically might offer the public a better deal.

These distinctions might seem inevitable, but they are not. At least in theory, it is possible to imagine a process of granting intellectual property rights that is more akin to an auction. A government agency, for example, might define an auction right, such as the exclusive right to nanotechnology, or the exclusive right to a particular technology or set of technologies within the nanotechnology field. ${ }^{90}$ Conceivably, such auctions might be the exclusive means by which the government granted intellectual property rights in inventions, though they also might be complements to the existing patent process. In the latter case, the right auctioned would be subject to existing intellectual property rights. The winner of the auction would then be granted an exclusive right to use any inventions subsequently developed falling within the scope of the patent right. Or, more narrowly and paralleling the approach of the existing patent system to improvements, ${ }^{91}$ the winner might receive only a "blocking" right to exclude subsequent inventors.

An initial objection might be that if such a system in fact were superior to the patent system, it would already exist. One cannot assume, however, that because a prospect system rather than an auction system evolves to determine rights to property, that the former is necessarily superior. When new property rights emerge, prospecting systems are likely to dominate auction systems regardless of their relative efficiency. Someone who stands a good chance of winning a race for a prospect has an incentive to lobby for the establishment of a prospect system based on a rule of first possession. ${ }^{92}$ No one has much incentive to lobby for the property right to be distributed through auction, since the competition of the auction would dissipate the rent from the property to be distributed. ${ }^{93}$ The difference is especially stark when

\footnotetext{
${ }^{90}$ For example, the right might be to any process providing for positional control in chemical synthesis. See Ralph C. Merkle, Molecular Manufacturing: Adding Positional Control to Chemical Synthesis, Chemical Design Automation News, Sept./Oct. 1993, at 1, available at http://www.zyvex.com/nanotech/CDAarticle.html.

91 See Mark A. Lemley, The Economics of Improvement in Intellectual Property Law, 75 TEX. L. REV. 989, 1000-13 (1997) (discuss patent doctrines related to improvement patents).

92 A rule of first possession also will tend to emerge because it is easy for a court to recognize. See, e.g., Richard A. Epstein, Possession as the Root of Title, 13 GA. L. REV. 1221, 1222-23 (1979). An auction regime requires some type of centralized administrative machinery.

93 The heterogeneity of potential prospectors will tend to reduce rent dissipation. See, e.g., Dean Lueck, The Rule of First Possession and the Design of the Law, 38 J.L. \& ECon. 393, 401 (1995); Wing Suen, Rationing and Rent Dissipation in the Presence of Heterogeneous Individuals, 97 J. PoL. Econ. 1384 (1989). The result is that the best situated prospectors can expect to receive a positive rent from a prospecting system. In an auction system, the best situated party also may receive a rent. In a second-price auction, for example, the winning bidder enjoys a rent equal to the difference between the highest and the next-
} 
someone has already found a prospect. The benefits of prospecting systems will tend, especially when new forms of property rights emerge, to be concentrated in a relatively small number of parties who will earn positive rents, while the benefits of auctions will tend to be far more diffuse. ${ }^{94}$ Only when legislators expect sufficient credit from creating a more efficient system, or a well-organized group emerges that would benefit indirectly from auctions, will distribution through prospecting tend to give way to distribution through auction. ${ }^{95}$

As a result, we must compare auctions to the patent system on the merits. Part of my purpose in performing this comparison is to amplify and elaborate the intuition that improving on the patent system with an auction mechanism is not straightforward. A patent auction system must include mechanisms for identifying the socially optimal scope of individual patent rights to be distributed, selecting the socially optimal private parties to possess the rights, and imposing on those parties socially optimal incentives to develop the rights. These are difficult analytic problems, and the risk inherent in adopting even a system that appears likely to provide better incentives than the patent system is high. My hunch is that, at least initially, the best explicit auction system that even a well-motivated committee could develop would be inferior to our existing patent system, which has benefited from evolution over time, even if the auction system served merely as an occasional complement to the patent system. My aim, however, is not to show that our patent system is necessarily superior to any explicit auction system that might be devised. To the contrary, the analysis will make the case for the patent system uneasy by identifying some potential benefits that conceivably might make even a relatively primitive patent auction system superior to the existing system. Nonetheless, the empirical uncertainties are such that immediate adoption of an auction system would be too risky.

\footnotetext{
highest bid. See generally William Vickrey, Counterspeculation, Auctions, and Competitive Sealed Tenders, 16 J. Fin. 8 (1961) (introducing the idea of a second-price sealed bid auction). Even in a first-bid auction, a party expecting to be the top bidder will bid somewhat less than its actual valuation to ensure that it will receive some benefit from winning the auction. Thus, there may be some incentive for well-situated potential bidders to lobby for the government to conduct an auction. Nonetheless, bidders are likely to be less heterogeneous with respect to their valuations at auction than with respect to their expected success in prospecting. A slight advantage in a prospecting race can lead to a large difference in the probability of victory, but only a small difference in the amounts that the participants would bid if the right were auctioned.

94 See generally MANCUR Olson, The LOGIC OF COLLECTIVE ACTION (1965) (noting the difficulty of organizing and mobilizing diffuse groups, and thus the difficulty these groups have in influencing the legislative process).

${ }^{95}$ A significant reason for a legislature to enact an auction scheme is because auctions are likely to generate revenue, and thus substitute for taxes or reduced spending in helping to balance budgets. See, e.g., Ellen P. Goodman, Digital Television and the Allure of Auctions: The Birth and Stillbirth of DTV Legislation, 49 FED. COMM. L.J. 517 (1997) (noting the billions of dollars the government received from spectrum auctions and observing that "the temptation to wring auction revenue from the broadcast spectrum was intense”). Non-cash auctions are less likely to be politically appealing than cash auctions.
} 
Part II.A will assess the principal effect of an auction system: its allowance of more expansive patent scope. We will assume that the patent auction system is a complement to the patent system, and that the patent is awarded to the bidder who agrees to pay the most to the government. At the same time, the analysis will anticipate a point in Part III, that different auction designs could be used to respond either to concerns that a broad property right might limit research and development or to concerns that it might increase deadweight loss. Part II.A assumes that an auction system would be well run, but Part II.B turns to the question of whether an auction system would be feasible to administer. It may be possible to identify technological areas for which the case for auctioning rights is particularly strong. Nonetheless, there is sufficient uncertainty that government should be quite hesitant to switch to a system of patent auctions, and thus the analysis here provides a tentative defense of patent races.

\section{A. The Effects of an Auction System}

The core of the case for an auction system is that it provides a truer realization of the prospect approach than a patent system can. The reason is that it could allow more expansive patents, along the dimensions of both time and technology breadth. Part II.A.1 explains how an auction system might facilitate more expansive patents, and notes that expansiveness might limit wasteful duplication associated with both patent races and inventing around. Part II.A.2 assesses more generally the consequences of broad auctioned patents for invention and development incentives and for pricing of patented products. Some of the concerns about broad patents can be mitigated through auction design, either to encourage greater spending on invention or to reduce monopoly pricing. ${ }^{96}$ Thus, the central question about a well-run auction system will turn out to be whether the concentration of research funds in a single patentee in fact advances social welfare, or whether there are other factors that counterbalance the benefit of decreased duplication of effort. Part II.A.3 will argue that technological fields in which spillovers are particularly likely present the strongest case for patent auctions.

\footnotetext{
${ }^{96}$ See infra Part III.
} 


\section{Enablement of Expansive Patent Scope}

\section{a. The Time Dimension}

Perhaps the most significant benefit of a patent auction is that it can provide for earlier patent protection. The benefit of this becomes clear through the lens of the Duffy model. ${ }^{97}$ Duffy assumes that some fixed number of identically situated firms will participate in the patent race, ${ }^{98}$ and his model shows that these firms will start racing earlier in a prospect system because that system reduces the cost associated with losing the race. ${ }^{99}$ If an auction provides for patent protection before a race even begins, the costs associated with losing the race disappear altogether. Firms that would not be willing to start racing in pursuit of a patent for some years might be willing to participate in an auction, because the costs of participating in and losing the auction may be less than the costs racing to create an invention and losing the patent race. Once a firm wins the auction, the value of research will be greater, because the firm can be confident that it will be able to internalize the benefits of research and development. Of course, the existence of the debate over the prospect theory suggests that a patent system may have some flexibility in awarding patents earlier or later. A patent system, however, will need to demand some degree of inventive achievement before a patent issues, and therefore will not be able to limit wasteful duplication as effectively as an auction system.

An auction system also could allow for longer patent terms, ${ }^{100}$ reducing the spillovers from invention. A 40-year patent term, for example, could considerably increase the benefits of both initial research and of commercialization relative to the status quo. ${ }^{101}$ A plausible objection is that if long patent terms are desirable, we could implement them easily in our existing patent

\footnotetext{
${ }^{97}$ See supra Part I.C.

${ }^{98}$ Duffy, supra note 20, at 469-70 (assuming “ $N$ identical firms," where $N$ is exogenous to the model).

99 The provision of early patenting does introduce the danger of inefficient delay by the patentee in developing the invention. See supra Part I.A. But, at least under some assumptions, the costs of this delay will be considerably less than the benefits of limiting duplicative effort. See Abramowicz, supra note 52, at 20-22 (elaborating on the Duffy model by allowing the appropriability of an invention to vary in a context in which two firms are competing for a patent).

100 An explicit auction system, however, could exacerbate the risk that inventions will not be commercialized. Suppose, for example, that the government auctions a 20-year patent term in an emerging technological field, but an inventor is unlikely to be able to develop an invention until at least 10 years of development. If the auction system is exclusive and replaces the patent system, then the inventor will have less of a patent term than the inventor otherwise would have had, and therefore not only might not commercialize the invention, but also might not have sufficient incentive to develop the invention in the first place. A nonexclusive auction system that complements the patent system will not produce this risk.

${ }^{101}$ Suppose, for example, that a patent is expected to produce \$1,000 per year in profit and can be commercialized after 10 years. Assume a $5 \%$ discount rate. With a 20 -year term, the patent in present value terms will be worth $\$ 4,978$. With a 30 -year term, the patent will be worth $\$ 9,909$, almost double.
} 
system, so the auction mechanism itself adds little. But a longer patent term might be more compatible with an auction system, for two reasons. First, in a patent system, longer nominal patent terms do not necessarily lead to longer effective terms, as inventors will seek to obtain patents even earlier. ${ }^{102}$ Because an auction bid will not be stronger if it is filed earlier, this is not a concern for an auction system. Second, a problem with long patent terms is that a "patent thicket” attributable to many patent being under private ownership could lead to significant transactions costs and holdout problems. ${ }^{103}$ Yet this will be less of a concern if a single patent covers an entire technological field, because such a patent does not by itself produce the problem of overlapping ownership.

\section{b. The Technology Dimension}

Explicit patent auctions might limit duplication not only by granting patent terms earlier and perhaps for longer periods, but also by defining broader rights than the patent system. Indeed, broader patents will be almost inevitable, since the specific inventions that will be developed cannot be known in advance. This will help limit the ex post duplication associated with inventing around and again provide the patentee with greater assurance of being able to internalize the benefits of research and development. If there really are efficiencies to broad patent rights, why couldn't our existing patent system afford such rights? A partial answer is that our patent system grants rights to claimed inventions rather than rights to scientific fields. Presumably, the patent system could grant rights to claimed inventions and close substitutes, with the degree of closeness possibly varying with the significance of the invention. Indeed, our patent system arguably already does that. In theory, "pioneer inventions"104 are entitled to broader protection than other patented inventions, and in particular to a broader range of “equivalents” for elements within the patent claim. ${ }^{105}$

\footnotetext{
102 See supra Part I.C. Indeed, in a model offered by Duffy in a separate piece, longer nominal patent terms can lead inventions to be placed in the public domain earlier, because the indirect effect of the longer patent term on date of invention can more than compensate for the direct term length effect. See Duffy, supra note 88, at 4-5.

103 For arguments that a "patent thicket" or anticommons problem may slow innovation even in the existing patent system, see Michael A. Heller \& Rebecca S. Eisenberg, Can Patents Deter Innovation? The Anticommons in Biomedical Research, 280 SCIEnCE 698 (1998); and Arti K. Rai \& Rebecca Eisenberg, Bayh-Dole Reform \& the Progress of Biomedicine, 66 LAW \& CONTEMP. PROBS. 289 (2003).

104 The Supreme Court defines a "pioneer invention" as "covering a function never before performed, a wholly novel device, or one of such novelty and importance as to mark a distinct step in the progress of the art.” Westinghouse v. Boyden Power Brake Co., 170 U.S. 537, 561-62 (1898).

105 See, e.g., John R. Thomas, The Question Concerning Patent Law and Pioneer Inventions, 10 HiGH TECH L.J. 35, 37 (1995).
} 
The pioneer patent doctrine appears to have fallen into disuse, ${ }^{106}$ however, and courts will invalidate broad claims if the patent does not sufficiently enable them. ${ }^{107}$ This doctrine could change, but granting patent scope far beyond the invention claimed is awkward when a patent system is based on the means to accomplishing certain results rather than on the results themselves. It would not be difficult in an explicit auction system for the government to define a right to any biochemical means of selectively inhibiting serotonin reuptake, or even more broadly to any biochemical means of reducing depression. ${ }^{108}$ But a patent system that granted such broad rights would face very difficult questions about just how broad they should be.

How powerful must the evidence be that a drug really inhibits serotonin reuptake before the inventor can receive the right to all drugs that might inhibit serotonin reuptake? A patent office might not be well equipped to determine whether an invention works well. ${ }^{109}$ Even where an invention unmistakably works, the patent office would still face difficult assessments of breadth. Should an invention that has a very slight impact on serotonin reuptake earn the right to all serotonin reuptake inhibitors or even all antidepressants? One danger is that inventors might develop inventions that themselves have very little usefulness because they think that the inventions will entitle them to broad patent rights to prospect for other inventions.

These considerations suggest that even if very broad patents are theoretically optimal, decisions whether to award them will almost necessarily be subjective, thus placing great demands on the patent office and injecting additional uncertainty into the research and development process. A patent auction system is a system that could make broad patents possible, if in fact they are desirable. A patent auction will be particularly useful if the optimal patent breadth is far beyond the scope of a typical individual invention, for example extending to an entire class of consumer goods. Once the patent office grants patents far beyond the scope of

\footnotetext{
106 See, e.g., Dan L. Burk \& Mark A. Lemley, Policy Levers in Patent Law, 89 VA. L. Rev. 1575, 1656 (2003) (“The pioneer patent rule has not been invoked by the Federal Circuit in recent years, leading some to consider it moribund, but it provides at least one factor to consider in deciding how broadly to apply the doctrine of equivalents.”).

107 See, e.g., O’Reilly v. Morse, 56 U.S. (15 How.) 62 (1854) (invalidating a claim to "all methods” for communicating with electromagnetic waves, because the patent specification had not disclosed all methods). For a discussion of $O$ 'Reilly and related cases, see Merges \& Nelson, supra note 11, at 845-50.

108 This does not mean that there would not be boundary questions. For example, if the right to all antidepressant drugs were auctioned, then the question would arise as to how a drug with some other primary purpose but also some antidepressant effects should be treated. Conceivably, the holder of the antidepressant patent might have a blocking right to these drugs, or a compulsory license regime might allocate profits in cases in which rights overlap.

109 Although patent law includes a utility requirement, see 35 U.S.C. $\S 101$, the patent office and the courts have interpreted the requirement loosely, considering scientific plausibility rather than efficacy. See, e.g., Nathan Machin, Prospective Utility: A New Interpretation of the Utility Requirement of Section 101 of the Patent Act, 87 CAL. L. REV. 421, 426-27 (1999).
} 
the particular means claimed, it might as well award intellectual property rights through auctions. Because a patent auction dissipates windfalls, it should generate less concern about arbitrarily providing rights that are broader than the patentee has earned.

\section{Effects of Expansive Patent Scope}

\section{a. Effects on Invention and Development Incentives}

An advantage of patent auctions is thus that they can facilitate expansive patent scope. That does not mean, however, that expansive patent scope indeed is desirable, even placing aside for now the question of deadweight loss from monopoly pricing. ${ }^{110}$ If an auctioned right is too broad, then the pace of innovation might slow. Because a rights holder still will be unable to appropriate the full value of the social benefits of inventions that it creates and commercializes, ${ }^{111}$ the auction winner might invest less in research than competitors in a patent system would invest in total in a particular field. The auction winner's incentives are analogous to those of a monopolist who chooses a lower quantity and higher price than is socially optimal. If the right auctioned were merely a blocking right, then third parties could continue to seek improvement patents. Even then, however, the transaction costs of reaching agreements with the auction winner, either ex ante or ex post, will discourage some innovative activity, perhaps inefficiently. ${ }^{112}$ Even if broad patents enable better coordination of inventive activity and reduce duplication, they might produce less inventive activity overall. This analysis rehearses with some additional nuances a standard argument that broad prospect patents might inhibit innovation by preventing full competition. ${ }^{113}$

We have already seen a sophisticated version of the opposing argument: A prospect system, like an auction system, will tend to make inventions occur earlier, because competition otherwise would reduce the expected value of participation in the inventive process. ${ }^{114}$ That argument is critical, because it clarifies that the debate about the prospect system is not merely about whether patents have some benefits independent of the classical reward justification for

\footnotetext{
110 See infra Part II.A.2.b.

111 See supra Part I.A.

112 Patentees sometimes may give away secrets through publication and obtain narrower patents, because they want to encourage improvers to improve inventions without worrying about transactions costs. See Oren Bar-Gill \& Gideon Parchomovsky, The Value of Giving Away Secrets, 89 VA. L. REV. 1857 (2003) (offering a theoretical and empirical case for this theory).

113 See sources cited supra notes 11-12.

${ }^{114}$ Duffy, supra note 20, at 470-72; supra text accompanying note 64 .
} 
patents, but also about whether granting patents early effectively increases the reward from engaging inventive activity. It does not, however, resolve the debate, which, like many theoretical debates in law, depends on empirical issues that might well be intractable and anyway vary from one technological field to another. My principal point is simply that the arguments for an explicit auction system that would allow for broader patents parallel the arguments about the prospect approach more generally.

Clear analysis of an auction approach, however, demands that two distinct issues about prospects be disentangled from the competing arguments and addressed separately. The first question is whether prospects will increase the aggregate level of investment across all inventors. On one hand, a broad prospect can reduce spillovers. If it would be worthwhile for a competitor to spend a dollar when able to capture only a small percentage of the benefits of research from that dollar, then it will also be worthwhile for the patentee to spend a dollar if able to capture a higher percentage of the benefits of research. On the other hand, a broad patent right will mean that a patentee might exploit only a small proportion of the possible inventions in the field, having little incentive to offer products that would compete with the winner's own initial inventions. It is possible, however, that reduced investment of this sort may increase efficiency, because imperfectly competitive markets can lead to excessive numbers of differentiated products. ${ }^{115}$ A patentee would still have incentives to make improvements to the extent that those improvements will increase aggregate demand for its products, but would not have incentives to make expensive improvements that would simply shift consumers from one product to a marginally better one. To the extent that a prospect approach decreases the aggregate level of investment, the investment foregone will disproportionately tend to be investment in products for which relatively strong substitutes already exist.

The second question is whether each dollar of investment will be spent more efficiently under competitive conditions than under centralized control. It is this issue that reveals the linkage between wasteful duplication and inventive accomplishment. To the extent that centralized control reduces wasteful duplication, each dollar of investment might be spent more

\footnotetext{
115 The product differentiation literature shows that excessive entry can occur in competitive markets, because each entrant fails to take into account the extent to which its product's sales come at the expense of products that already exist. See, e.g., Steven C. Salop, Monopolistic Competition with Outside Goods, 10 BELL J. ECON. 141, 142-45 (1979) (developing a model in which excess entry occurs); Avinash K. Dixit \& Joseph E. Stiglitz, Monopolistic Competition and Optimum Product Diversity, 67 Am. Econ. REV. 297 (1977) (developing a model in which excess or insufficient entry can occur). To the extent that monopoly rights may decrease the number of new inventions, that counterintuitively may enhance efficiency.
} 
productively. This is not inevitable, however. Perhaps patent monopolists will allow too much slack in their development apparatus because they will not feel competitive pressures, or perhaps they will blind themselves to the possibility that alternative research paradigms might prove successful. ${ }^{116}$ These possibilities might depend in part on the structure of business organizations that purchase patent auctions. A business organization that borrows to finance its bid in a patent auction, for example, might feel considerable pressure from creditors both to produce results and to consider alternative points of view. ${ }^{117}$ Ultimately, it is on this second question that the wisdom of patent auctions most turns. Changes to the auction structure can encourage increased expenditure on research and development, ${ }^{118}$ but if centralized control inherently is a bad approach to distributing R\&D dollars, then patent auctions are unlikely to be successful.

\section{b. Effects on Deadweight Loss}

Whatever their effect on incentives to invent, broad and long patents have a serious drawback: an increase in deadweight loss. First, broad patents mean less competition among substitutes, and thus higher prices. We have seen that inventing around can be socially costly, because the prospect of duplicative research might delay investment in a field, but it does have the salutary ex post consequence of reducing prices and increasing competition. Second, and probably of somewhat lesser importance, a broad exclusive right to development in a field will encompass even inventions in the field that in a traditional patent system might have been placed instead in the public domain. Some inventors might place inventions into the public domain because they hope to encourage others to improve them, ${ }^{119}$ perhaps because the inventions are complements to products or services of the original owner of the intellectual property right. Others might simply be public-spirited. Explicit patent auctions might result in fewer inventive gifts, because the winner of a right to prospect in a field would be able to prevent the gift-giving.

The concern about deadweight loss reinforces a critical point: Patent auctions do not provide an escape from patent law's fundamental tradeoff between static and dynamic

\footnotetext{
116 See, e.g., Wu, supra note 11 (offering an extended version of this argument)

117 We cannot learn much empirically about how patent auctions would work by considering the behavior of firms that have already profited from broad patents. See, e.g., Merges \& Nelson, supra note 11, at 884-908 (providing specific examples of firms that slowed the pace of innovation after receiving patents). Inventors who have already covered research expenses many times over might be less efficient than inventors who will need to produce phenomenal results to avoid the costs of an auction.

118 See infra Part III.A.

${ }^{119}$ See Bar-Gill \& Parchomovsky, supra note 112.
} 
efficiency. ${ }^{120}$ The case for patent auctions will appear strongest to someone who is willing, at least in some technological area, to tolerate some additional cost in static efficiency for gains in dynamic efficiency but recognizes that the standard policy levers of patent law are too crude to make expansive patents efficient. Nonetheless, even someone who believes that patent law errs too much on the side of dynamic efficiency, tolerating too much monopoly pricing to justify the improvements in incentives to invent, might endorse patent auctions. As we will see below, ${ }^{121}$ altering the structure of the auction makes it possible for the government to alter the tradeoff between static and dynamic efficiency. Although a significant empirical question will be what tradeoff any particular auction structure provides, the central question is whether patent auctions will provide more social welfare from inventions for a given cost in the form of deadweight loss. Patent auctions might be able to accomplish this by granting broader rights across the dimensions of technology and time, while nonetheless constraining deadweight loss by reducing patentee power along the dimension of price. And thus, while deadweight loss must be a central consideration in the design of a patent system and in the design of an auction system, it may be less important than the question of whether centralizing investment resources is on balance a benefit or a cost.

\section{The Best Case Scenario}

We have so far treated the choice of whether to adopt an auction system that would complement the patent system or rely solely on the patent system as an all-or-nothing decision. The government, however, could sponsor an auction for only a single technological field or for a limited number of technological fields, presumably selecting fields in which the case for the auction system is strongest. The case will tend to be strongest when the danger of spillovers is greatest. Thus, patent auctions might be most appropriate in nascent technological fields that will depend on many small contributions and for which multiple patent generations of research are likely to be needed before the most significant commercial applications materialize. In some inventive contexts, the first generation of research might produce as much profit per research dollar as subsequent generations, but there are other fields in which that might not be so. Consider, for example, nanotechnology. This field has already produced some commercial

\footnotetext{
${ }^{120}$ See supra note 28 and accompanying text; notes 53-54 and accompanying text.

${ }^{121}$ See infra Part III.
} 
products, such as a tennis racket composed in part of strong but light nanotubes, ${ }^{122}$ but these are relatively meaningless compared to what nanotech enthusiasts envision for the future. ${ }^{123}$ It might be that the primary social benefits of the first twenty (or more) years of nanotechnology research will be for later innovation, ${ }^{124}$ perhaps even mostly innovation beyond the patent term of inventions patented in this period. Inventors might be able to appropriate only a small portion of the social value of their inventions, and the result is that the patent system would provide insufficient incentives to innovate. ${ }^{125}$

Patent auctions, of course, are not the only possible solution to this problem. We have seen, for example, that patent terms could be extended, perhaps to thirty years or fifty years, and that one concern of such extension is that long patent terms might create a "patent thicket.” 126 Transactions costs would make it difficult or at least expensive to take advantage of the building blocks of innovation. There is, however, an even more significant problem. Such a regime might produce relatively little incentive to engage in the type of basic research that does not produce patents, research that results in information rather than inventions. Inventors can keep information as trade secrets, but in a rapidly developing field like nanotechnology, it will be difficult to develop information that others will not also develop before some basic research can easily be commercialized. Awarding a patent to a field like nanotechnology might have relatively little downside, if there would otherwise be relatively few meaningful nanotechnology products

\footnotetext{
122 http://www.smalltimes.com/document_display.cfm?document_id=2506 (last visited June 15, 2005) (discussing the Babolat tennis racket).

123 See, e.g., http://www.nanobot.info/ (last visited July 15, 2005) (trumpeting the possibility that "nanobots” will be able to interact with cells in the treatment of disease); see also Mark A. Lemley, Patenting Nanotechnology 1-2 (Stanford Law Sch. John M. Olin Program in Law \& Econ. Working Paper No. 304, June 2005). Lemley notes that patents in nanotechnology have been issuing at a rapid pace for a new technology. Lemley, supra, at 4-5. This suggests that the patent system may well be contributing to incentives to innovate, but these incentives may still be suboptimal.

${ }^{124}$ Cf. Lemley, supra note 123, at 32 ("Nanotech inventions will require substantial investment that will not be recouped for a long time, if ever.”).

125 Another example is anti-aging research. Aubrey de Grey argues that such research might result in dramatic life extension for mice within 20 years, and for humans within 15 to 100 years after that. See Aubrey de Grey, Timeframe for Progress in Life Extension, http://www.gen.cam.ac.uk/sens/time.htm (last visited July 15, 2005). Perhaps this is wildly optimistic. For our purposes, the key point is that even if scientists and entrepreneurs thought that the goal of eliminating aging might be achievable in 50 years, relatively little private capital would be aimed directly at this goal, because of the short patent term. The field thus advances only to the extent that it is funded through basic research or as a result of spillovers from other medical research. Auctioning a very long patent on the envisioned anti-aging technologies could do little harm if the technologies seem unlikely to develop in the absence of such a patent anyway.

126 See supra note 103 and accompanying text. Lemley suggests that the patent thicket may be a greater problem in nanotechnology than in earlier emerging technologies because of the greater number of patents, some overlapping, on building blocks. See Lemley, supra note 123, at 20.
} 
anyway. The patent system should be least controversial when it produces inventions that otherwise would not have existed, ${ }^{127}$ and the same should be true for patent auctions.

Such a patent might generate far greater research incentives than the existing patent system could provide. The party that wins the patent over the field would recognize that it would be able to appropriate benefits of the research even if those benefits did not emerge for fifty years, and if the eventual potential payouts are sufficiently large, modern capital markets should be able to support such long-term project development. The caveat is that potential third parties would be less likely to engage in research, because they would need permission from the party holding the patent over the field to market their inventions. Especially in the early years of the patent, however, the patentee would likely be quite willing to enter into relatively favorable agreements to encourage third parties who receive patents within the scope of the auctioned patent grant, because the auction patentee would receive the entire benefit of any individual invention after the patent term on that invention expired. The auction patentee might even offer third-party improvers better deals than they would receive in the patent system alone. The auction winner could, for example, commit not to block any patents developed in the early years of the patent system.

To be sure, government subsidies furnish an alternative model for generating basic research, and such subsidies might be superior to an explicit patent auction. ${ }^{128}$ But some critics suggest that the government does not do an effective job in allocating scientific resources, and scientists do not have optimal incentives to invest in projects most likely to produce long-term welfare increases. ${ }^{129}$ If the patent system is superior to a governmental subsidy system in identifying projects likely to have an eventual payoff, then an explicit auction system might be preferable to the existing regime. With sufficiently broad patent terms and long patent scope, the auction winner will have incentives directly to sponsor research, but will have strong incentives to ensure that the research it subsidizes will in fact produce benefits for the field. Thus, even if

\footnotetext{
127 Some have argued that patents should be granted only on inventions that would not have been developed in the absence of patent law. See, e.g., A. Samuel Oddi, Beyond Obviousness: Invention Protection in the Twenty-First Century, 38 AM. U. L. REV. 1097, 1101 (1989). A problem with such proposals is that it is difficult to determine the extent to which patent law has accelerated an invention.

${ }^{128}$ See generally LANDES \& POSNER, supra note 87, at 306-08 (considering whether there is adequate funding for basic research and whether patent law should protect it).

129 See generally Thomas O. McGarity, Peer Review in Awarding Federal Grants in the Arts and Sciences, 9 HIGH TECH. L.J. 1, 39-42 (1994) (critiquing the peer review system and considering the possibility of radical alternatives to peer review).
} 
the model of dispersed, competitive research is indeed more efficient than patentee-directed research, the auction patentee should have incentives to subsidize such research, recognizing that because of its patent, it will receive much of the benefit of such research. The government could even decide to subsidize such research if the level of private investment seems unlikely to be adequate, for example by promising at the time of the patent auction that it will match at some ratio research grants provided by the auction winner. This hybrid regime would combine public support for research with control by a strongly incentivized private party.

\section{B. Administration of an Auction System}

Although the above argument suggests that patent auctions in selected fields might increase welfare, the empirical uncertainties are sufficient to counsel at least against bold experimentation, and because the fields in which auctions might seem most useful are emerging fields, virtually any experimentation might turn out to be bold. Even if we could be sure theoretically that there exist technological fields in which patent auctions would be efficient, the question remains whether the government could do a good enough job in identifying the relevant fields. Perhaps the most logical approach would be to create an administrative agency, but of course that only begs the question. Part II.B.1 elaborates on the difficulties associated with governmental identification of property rights to be auctioned, and Part II.B.2 points out that an auction regime might be particularly problematic if the government does not act quickly enough or sets a less than optimal patent term. Finally, Part II.B.3 considers the administrative cost of an auction apparatus relative to the patent system, suggesting that this plausibly would be a benefit of an auction system, though not enough of one to allay concerns.

\section{Property Right Delineation}

In a patent system, the government's role is reactive. Officials at the patent office must decide whether to approve patent applications, and they might insist that excessively broad claims be removed from a patent application before approval, ${ }^{130}$ but they do not need themselves to draw boundaries around different patentees' intellectual property rights. As Aditya Bamzai

\footnotetext{
${ }^{130}$ When a patentee through amendment narrows a patent application to meet the requirements of the Patent Act, the doctrine of prosecution history estoppel will limit the patentee's ability to claim infringement under the doctrine of equivalents. See Festo Corp. v. Shoketsu Kinzoku Kogyo Kabushiki Co., Ltd., 535 U.S. 722 (2002) (clarifying the prosecution history estoppel doctrine, and noting that amendment by itself does not conclusively bar application of the doctrine of equivalents).
} 
has pointed out, “[a]uctions are ... less useful when government policy aims to induce private investment in the discovery of new goods, and more useful when the government has already identified the good in question." 131 Bamzai cites intellectual property as an example of this general point, noting that "the auction method requires that the government know what it is auctioning off.”" 132 Indeed, a system of intellectual property auctions presumably would require the government to identify, preferably with some precision, the rights that the winner of the auction will receive. ${ }^{133}$

For example, government officials might come to recognize that pharmaceutical companies will soon begin experimenting with a certain class of drugs, and it might then auction the right to the entire class of drugs. To do so, the officials would need themselves to figure out how to define the relevant class of drugs: through a chemical definition, a functional definition focusing on the purposes of the drugs, or some combination. The government might solicit private input, but ultimately it would be responsible for determining when to auction intellectual property rights and how to define those rights. The government might err in choosing the best definition. Poor decisionmaking could lead to inefficient deployment of investment resources, and it could lead to litigation. More troublingly, there also might be false positives or false negatives in the government's decision about whether an intellectual property auction would be appropriate in a given field.

If the government fails to auction an intellectual property right when it should, or auctions off a right of inefficiently narrow scope, then little is lost, at least assuming that the patent system continues to operate alongside a governmental auction. False positives and excessively broad rights are of greater concern. The possibility of auctioning rights that are considerably broader than any patent likely would be provides both the greatest benefit and the greatest risk of patent auctions. ${ }^{134}$ If the patent system already produces patents of optimal breadth, then allowing the government to auction broader rights can only cause harm. If there might be occasions in which broader patents would be appropriate, as the analysis in Part II.A suggests, the question becomes whether the government sometimes will auction rights that are

\footnotetext{
${ }^{131}$ Aditya Bamzai, Comment, The Wasteful Duplication Thesis in Natural Monopoly Regulation, 71 U. CHI. L. REV. 1525,1546 (2004). 
too broad, and whether the benefits from the occasions when the government improves social efficiency by auctioning broad rights will outweigh the costs when the government goes too far.

This is a difficult question to answer in the abstract, and one's answer to it might well say as much about one's attitude about governmental competence as about the particulars of the context. Even for optimists about governmental competence, however, governmental error must loom as a large concern. Governmental employees of extraordinary intellect and probity could easily err, because the analytical question of when an auction should occur rests on empirical issues of extraordinary difficulty. There are two reasons for this. First, the future development of technological areas is difficult to anticipate; some scientific problems may prove considerably easier or harder than policymakers currently think. An auction will be most useful in a research context in which spillovers are relatively likely, but it may be difficult to predict in advance whether such spillovers will occur. For example, in a particular technological field, a line of research might yield a blockbuster patent that would allow researchers to achieve a dominant market position in that field, suggesting that auctions will not be necessary, or many small contributions might advance the field but in ways that will be difficult to commercialize. Similarly, in some technological fields, patent races might produce a great deal of redundant effort, suggesting that early property rights will be useful, while in other fields, there might be so many independent lines of inquiry that competition will produce little wasteful duplication. Identifying the characteristics of different technological areas is no easy task, especially for emerging technologies, where future scientific studies might change our assumptions about market structure.

Second, the empirical economics are no easier. The case for auctions is an extension of the prospect theory of patents, ${ }^{135}$ but that theory remains controversial. ${ }^{136}$ In my view, Duffy makes a strong case for prospect theory that calls into question past critics of the theory. The essence of his theoretical argument, however, reveals the difficulty of empirical analysis. A promise of early declaration of a winner in a patent race should lead inventors to devote resources earlier they otherwise would (and similarly an early explicit auction would better able inventors to recoup investments). But the theoretical model itself cannot give us a clear sense of

\footnotetext{
135 See infra text accompanying note 113.

136 See supra note 11 and accompanying text. The ultimate question in the auction context is whether auctioning prospects would increase useful inventions. See infra Part II.A.2.a.
} 
the magnitude of this effect, ${ }^{137}$ or of how it compares with countervailing effects. ${ }^{138}$ Because patent policy is uniform, it would be difficult to measure the extent to which the possibility of broad patent rights in fact leads to earlier and greater commitment of resources to research and development. Thus, the frequency with which an auction regime will beat the status quo depends on empirical issues that might be unresolvable. Although this Article's aim is to suggest that auctions plausibly could improve our innovation policy, certainly too many auctions could be inefficient, and there are no tools for determining how often auctions would be efficiencyenhancing.

\section{Timing}

Identification of a technological field to auction does not end the government's task in delineating the property right. The government must also determine the optimal length of the right to be auctioned. Too short a patent term would increase the risk that the patent will not be developed if research does not go as planned and might frustrate research in the interim. With too long a patent term, future deadweight loss from patented inventions that would have been created anyway might be unnecessarily high. The project of determining the optimal term for an explicit auction is beyond the scope of this Article, and it might well be a difficult task. Moreover, it might be impossible to determine the optimal term in advance. Any area of technology might develop faster or slower than originally anticipated. At least for the foreseeable future, an explicit patent auction of this type would probably be advisable only in a technological area in which one could be confident that little progress otherwise would be made over the prospective patent term in the absence of an explicit auction. This would probably exclude nanotechnology, for example, even though that might provide a stronger case for an auction than many other fields.

As important as the issue of when the auctioned patent right should end is the issue of when the patent auction should take place. If an auction occurs late, then it of course will not stop the patent race; even if racers anticipate the possibility of an auction of a field after receipt

\footnotetext{
137 A significant caveat to Duffy's theory is that implicit auctions cannot work when unanticipated exogenous shocks suddenly make attractive an invention that previously seemed unattractive. See infra note 161 and accompanying text. The empirical question is whether the inventive process is ordinarily smooth and predictable, or whether possible inventions often suddenly become apparent, triggering destructive races.

138 See, e.g., Wu, supra note 11 (arguing that centralized decisionmaking about invention might be less efficient than decentralized decisionmaking).
} 
of a patent within the field, the auctioned right would exclude the scope of earlier patents and thus have only indirect implications. ${ }^{139}$ The troubling case is that the auction might occur after racing has started but before a patent has issued. Potential inventors might not race because of the concern that the race will be cancelled while in progress by the announcement of an auction, potentially causing loss of research effort. Perhaps not all is lost for a leading inventor who loses the auction; the inventor might win the auction or sell the research results to the winner, ${ }^{140}$ either directly or after completing research and seeking a patent within the scope of the auctioned right. ${ }^{141}$ But the value will be considerably less, and so anticipation of a possible auction will deter racing. The welfare implications are ambiguous. The anticipation of a patent auction might not only hinder inefficient duplicative behavior, but also delay inventive activity. The case for explicit patent auctions might be strongest if the government makes decisions to conduct an auction either early or not at all.

\section{Cost}

The necessity for governmental administration of the auction process might be of concern not only because the government might make bad decisions, but also because the process itself might itself be expensive, and yet leave many unanswered questions for further expensive litigation. Conceivably, administrative expense might be an advantage of explicit auctions, however. Assuming the auctioned rights will at times be broader than rights that later would be received in a patent system, the total social cost of delineating these rights is likely to be lower. As in all property contexts, there inevitably will arise disputes about the scope of the rights that the government has auctioned, and if the government is not skilled at defining rights, that might increase both the government's costs in defining rights initially, and the costs of the courts and private parties in litigating disputes that arise.

\footnotetext{
139 For example, one might be more willing to race for a patent if the remainder of the field in the future will be auctioned, because the winner of the race may face fewer substitutes than in a world in which racing begins anew.

140 The sale, however, might be impeded by Arrow's Disclosure Paradox, that it is difficult to sell information without disclosing it or to disclose information without giving it away. See Kenneth J. Arrow, Economic Welfare and the Allocation of Resources for Invention, in The RATE AND Direction Of INVENTIVE ACTIVITY: ECONOMIC AND SOCIAL FACTORS 609 (1962).

141 This could be accomplished only if the auctioned right is for an improvement patent only. See supra note 91 and accompanying text.
} 


\section{PATENT RACES VS. PATENT AUCTIONS}

Auctioning broad patents, however, eliminates disputes about boundaries of patents that otherwise would have been issued within the scope of the auctioned right. ${ }^{142}$ The administrative costs of auctioning a field are likely to be less than those of granting patents to each invention that occurs within a field. This advantage of auctions will be considerably lessened if the auction system is merely a complement to the patent system. Even if the auctions are only for a right to exclude and the government continues to issue improvement patents within the scope of the initial auctioned right, however, the number of patents issued to parties other than the auction winner is likely to be less than if no right were originally granted. ${ }^{143}$ The auctioning of the broad right might deter some would-be inventors within a field, and so the number of disputes will likely fall.

In general, awards of broad property rights have a significant downside: increased rentseeking. ${ }^{144}$ As we have seen, however, there is relatively little incentive for potential bidders to lobby the government to have an auction. ${ }^{145}$ Nor is there much reason to lobby, given an auction, for the right to be relatively broad rather than narrow, if the auction itself is expected to dissipate the rent either way. A well-organized consumer group might lobby, but its interests at least in theory ought to be roughly aligned with those of the public in any event. Some rent-seeking activity undoubtedly will occur and will have an inherent cost because not all auction participants are equally situated. In addition, the occurrence or even the possibility of auctions will lead parties to invest in acquiring information, perhaps in excess of the efficient level, in order to maximize their success in the auction. Nonetheless, the extreme concern of capture by private interests and dissipation of rents in the capture process does not seem likely here. If the

\footnotetext{
${ }^{142}$ A drawback is that an auction system might produce less disclosure of the results of invention. Some disclosure would still occur, however, to the extent that patents would be allowed within the scope of the patent grant. There is considerable doubt about how much of a benefit mandated disclosure provides. See Note, The Disclosure Function of the Patent System (or Lack Thereof), 118 HARV. L. REV. 2007 (2005) (arguing that the patent system is failing in the goal of disseminating information). If mandated disclosure is considered a significant benefit, the law might seek to require an auction winner to reveal the results of subsequent research within the patent term.

143 See Duffy, supra note 20, at 488-89 (showing that the owner of a blocking right has significantly greater incentives to conduct research within the scope of that right than third parties).

${ }^{144}$ Rent seeking is an activity in which the competition for rents, for example from an exclusive government franchise, dissipates the benefits of those rents. See Anne O. Krueger, The Political Economy of the Rent-Seeking Society, 64 AM. EcON. REV. 291 (1974) (introducing the term); Gordon Tullock, The Welfare Costs of Tariffs, Monopolies, and Theft, 5 W. EcoN. J. 224 (1967) (offering an additional seminal treatment).

145 There may, however, be incentives for an inventor with a chance to win a patent race to lobby against an auction. A system of patent auctions thus might produce costs associated with rent opposition. See Robert Cairns \& Ngo Van Long, On Opposition to Rent Seeking: Implications for Developing Countries, 2 REV. DEv. ECON. 282 (1998) (noting that the full costs of rent-seeking activity must include the costs of those opposing the granting of rents).
} 
government makes mistakes in running patent auctions, those mistakes are more likely to be the result of bungling than of bad faith.

\section{Additional Objections and Caveats}

The difficulty of administering an auction regime thus presents a formidable obstacle to implementation of patent auctions. Concerns about whether the patentee will have sufficient incentive to invent and whether the patentee will charge too much for inventions are additional concerns, though we will see in Part III that auction design can greatly alleviate these. This section considers a few other significant objections to a patent auction regime. Some of these demand important caveats, while others seem less worrisome.

\section{International Cooperation}

A formidable practical objection is that intellectual property law is negotiated internationally, ${ }^{146}$ and so adoption of a radical change to patent law such as the institution of a patent auction mechanism would require international cooperation. The prospect of this seems even worse than the prospect of domestic adoption. Even in the absence of international commitments, any individual country has only a limited incentive to sponsor patent auctions. The sponsor would bear the costs of the auctions, for example in the form of research subsidies or higher costs for its customers, but would receive only a small portion of the benefits. Ironically, then, patent auctions might be most feasible if international cooperation increased, and a centralized authority were to decide that an experiment, perhaps in a relatively obscure technical area, would provide sufficiently valuable information to make it worthwhile.

\section{Technology Suppression}

An additional concern is that a firm might seek to buy a patent simply to prevent competition and to suppress new technology development. This is an old story about the patent system, represented by David Mamet’s play The Water Engine. ${ }^{147}$ Some scholars have pointed to cases in which market actors have used patents to protect their existing market position without

\footnotetext{
146 For an overview, see Intellectual Property And International Trade: The TRIPS Agreement (Carlos M. Correa \& Abdulqawi A. Yusuf eds., 1998).

147 David MAMet, The Water Engine: AN American FABle (1978). For a plot summary, see http://www.imdb.com/title/tt0105788/ (last visited Feb. 24, 2006).
} 
developing the underlying technologies. ${ }^{148}$ Patent auctions might appear to facilitate technology suppression, because it would be more difficult to invent around relatively broad patents. There is, however, a strong reason to believe that technology suppression in fact will not occur much with patent auctions: Broad auctioned patent rights are so attractive that they will be very expensive, far more expensive than development of individual inventions within the scope of the auctioned right. Firms will rarely be able to buy these broad rights and then not develop them.

Suppose, for example, that in 1985, the government auctioned a 50-year patent on all digital camera technology. Kodak certainly might have considered bidding on such a patent, because its expertise in photographic technologies might be in a good position to exploit the technology. But suppose digital technology seemed likely to be worth considerably more than the rents Kodak was earning from film technology, say \$3 billion rather than $\$ 1$ billion in present discounted value terms. Kodak would not be able to spend $\$ 3$ billion to protect only $\$ 1$ billion in rents. That price would indicate that competing bidders expected the rents from digital technology to be worth about $\$ 3$ billion more than the cost of developing the technology. Kodak, like other possible bidders, would be better off developing the technology than suppressing it if it won the auction.

Suppression seems possible only when the potential profits from exploiting the new technology area are no greater than the rents that already exist. Suppose, for example, that digital cameras were expected to produce discounted rents of $\$ 2$ billion, but only if the firm were to spend \$1 billion on development cost. The cost to Kodak of acquiring the auctioned patent would then be about $\$ 1$ billion, so in this case it would be a close call whether to develop the technology. With a slightly lower expected benefit from the new technology, or a slightly higher expected cost of developing the technology, it would make sense for Kodak to bid with the intention of technology suppression. Of course, Kodak might bid with this intention and then change its mind and develop the technology, if the expected benefit of the new technology increased or the expected cost decreased. Indeed, it would almost always make sense to perform at least some research to determine whether the patent is worth exploiting.

For three reasons, the possibility of such technology suppression seems easily avoidable. First, the analysis assumes wrongly that an incumbent firm will be able to protect its monopoly

148 See, e.g., Kurt M. Saunders \& Linda Levine, Better, Faster, Cheaper-Later: What Happens When Technologies Are Suppressed, 11 Mich. Telecomm. \& TeCH. L. ReV. 23 (2004). 
position simply by suppressing new technology. This is highly unlikely, however, if its existing patents will eventually expire, allowing other firms to enter the market. Second, such technology suppression can be avoided simply by auctioning patents that are relatively broad in comparison with existing patents. Third, auction design can eliminate concerns about technology suppression. In particular, an auction in which the winner is the party promising to spend the most money on R\&D will ensure that some technology development will occur. ${ }^{149}$

That does not mean that auctions always should be designed to avoid technology suppression. Counterintuitively, technology suppression might be beneficial in the rare cases in which it might be profitable. At least in the absence of spillovers, it does not make sense to encourage an auction winner to spend more than $\$ 1$ billion in present discounted value, if that will kill a market that would provide $\$ 1$ billion in social value and replaces it with a market that would provide $\$ 2$ billion in social value. Reducing research and development that produces relatively redundant technology, i.e. discouraging inventing around, ${ }^{150}$ can increase social welfare. ${ }^{151}$ It is thus only because of spillovers, social benefits from innovation that the patent auction winner cannot capture, that there could in theory be situations in which technology suppression would benefit the suppressor but be harmful from a social standpoint. Even where technology suppression would be socially costly ex post as a result of such spillovers, a system that tolerates it might produce social benefits by encouraging research and development that would lead to the technology and the market position that would allow a firm to engage in it. A regime that allows a patentee to suppress some technology beyond the scope of the patent in effect is a regime that allows for broader patent scope. So, technology suppression might be beneficial ex post and especially ex ante, but if not, patent auctions can easily avoid it.

\section{Irrational and Mistaken Bids}

Inefficient technology suppression might still occur if a firm decided to purchase a broad patent and not develop it, even though the net effect of doing so would be to lose a great deal of money. This is one species of potentially irrational or mistaken bidding that might lead a patent to be allocated to an entity that is not in the best position to develop the area. Irrational

\footnotetext{
149 See infra Part III.A.

150 See supra note 16.

151 The product differentiation literature relatedly shows that because of the fixed costs associated with entering a market, excessive entry from a social perspective can occur. See supra note 115 and sources cited therein.
} 
expenditure could be a problem in the existing patent system too, but wasted expenditures, though a social cost themselves, should not deter others from investing in research and development. How serious a problem irrational and mistaken bidding would be for patent auctions depends on the degree to which capital markets and corporate law can succeed in restraining irrational behavior by corporations. Because of the large amount of money involved, a firm that won a patent that it was not in the best position to develop would face considerable market pressure to sell the patent to another firm, possibly including a hostile takeover bid. If concern about irrational corporate behavior were sufficiently significant, it might make sense for the patent auction authorities to allow bids only from corporations that leave themselves vulnerable to capital market discipline, excluding for example corporations that have adopted “poison pills.” 152

\section{Small and Independent Inventors}

Another objection is that patent auctions might freeze out independent inventors, even though such inventors might offer considerable contributions. Of course, some scholars have suggested that patent law is already hostile to independent inventors. ${ }^{153}$ At least in theory, independent inventors are free to tinker in their garages, though in practice research and development of significant technologies typically requires so much time and money that often some form of venture capital is required. Whatever role remains for independent inventors in the existing patent system, patent auction winners almost certainly would be large entities. Of course, these large entities might still hire or enter into other arrangements with independent inventors, but then they no longer would be wholly independent. If the auctioned right is merely a blocking right, ${ }^{154}$ independent inventors might still exist, though their incentive to invent might be lower. So, some inventors might continue to invent independently, some would affiliate themselves with large entities, and perhaps some would decide to pursue other activities altogether. The economic question is whether anything would be lost by the elimination or

\footnotetext{
152 For the classic argument that a target firm's management should be passive in the face of a hostile tender offer, see Frank H. Easterbrook \& Daniel R. Fischel, The Proper Role of a Target's Management in Responding to a Tender Offer, 94 HARV. L. REV. 1161 (1981).

153 See, e.g., Ivar M. Kaardal, The American Inventors Protection Act, the Independent Inventor's Interest \& Consumer Choice in the Market, 84 J. PAT. \& TRADEMARK OfF. SOC’y 503 (2002).

${ }^{154}$ See supra note 91 and accompanying text.
} 
reduction of the opportunity to invent independently. This should count as a subissue to the broader issue of the efficiency of centralizing inventive activity. ${ }^{155}$

\section{The Design of PAtent Auctions}

We have considered so far the most obvious approach to structuring an auction, in which the auction winner is the party that offers to pay the government the largest amount of money for the right. Any auction currency provides an alternative outlet for rent dissipation, thus potentially reducing less efficient types of rent dissipation, for example from patent races and inventing around. The choice of bid form matters, however, because the means by which the auction dissipates rents might impact its efficiency, and the ideal currency should promote a form of rent dissipation that promotes efficiency, given the tradeoffs of a patent system. Duffy's analogy of the patent system to an implicit auction in which the winner is one of the inventors who agrees to accept the earliest patent expiration ${ }^{156}$ suggests an alternative possibility, that the government could provide the intellectual property right to the party that agrees to accept it for the shortest patent term. The patent term currency ensures that prospective inventors dissipate rents by agreeing to accept shorter patent terms, thus assuring the public that monopoly pricing will not last as long.

This cannot be a complete solution, however, because someone might bid for a zero term (or a term just above zero). At the very least, the government would need to insist that the winning bidder (or perhaps each bidder) pay some nontrivial amount of cash to the government to discourage frivolous bids of excessively short terms. Even placing the possibility of such frivolous bids, however, the inventor willing to commit the invention to the public for the longest period of time might end up not committing as socially beneficial an invention to the public. The greater the concession an inventor makes to the public, the less the incentive the inventor will have to develop inventions within the scope of the patent. Indeed, it may be desirable to use a rather different auction currency, one that will dissipate rents not by enhancing the public domain but by increasing the incentive of the inventor to engage in research and development. For example, the patent might be awarded to the bidder that agrees to commit the most resources to research and development. There is thus a fundamental tradeoff in auction design: The auction

\footnotetext{
${ }^{155}$ See supra notes 11-16 and accompanying text (discussing the issue without taking a position on it).

${ }^{156}$ See supra Part I.C.
} 
designer can seek to limit deadweight loss, to increase incentives to invent, or some compromise between the two, but the tradeoff nevertheless exists.

Ultimately, this tradeoff makes the case for switching to patent auctions unappealing, or at least not unambiguously superior to the existing system. If we can be confident that the principal problem with auctions of broad patents would be increased deadweight loss, then an appropriate auction design could combat that problem, but if the problem instead is that inventors will invent too little within the patent scope, that auction design will not work. In reality, both concerns are likely to be problems to some extent, and although that is no different from the situation in the existing patent system, it is difficult to anticipate in advance the optimal tradeoff. Our patent system in effect is an implicit auction in which bids are paid in two currencies, cash for prepatent investment and patent terms. This dual currency approach produces some balance between the problems of deadweight loss and patent nondevelopment. As the patent system moves more toward a pure prospect system in which less investment is required to obtain a patent, inventors will register their prospect patents earlier, leading to shorter effective patent terms. This means less deadweight loss and less research and development. An explicit auction system might lead to a different tradeoff, but it would be impossible a priori to establish that any particular auction design would produce a better tradeoff.

Part III.A discusses auction approaches that seek to maximize research and development. Part III.B then considers the possibility of auctions that seek to reduce deadweight loss. In addition to the least-patent-term auction, one can imagine other auction currencies that in effect would force the patentee to make concessions on price in charging for patented products. A patent might be awarded to the party that agrees to accept the lowest proportion of patent damages, to accept compulsory licenses at the lowest proportion of what the government determines to be fair, or to price all patented products at the lowest percentage of what government officials decide through a system of price regulation. In all of these cases, the auction winner would also need to pay some fixed amount of cash, to ensure that the winner will have some incentive to develop inventions within the patent scope.

\section{A. Auctions to Stimulate Development}

The "all cash" auction will tend to provide some assurance that the winner intends to develop the invention within the patent scope. Just as a patentee will rarely go through the 
process of creating and patenting an invention if there is no chance that the patentee will ever commercialize the invention, ${ }^{157}$ a bidder will not offer a large amount of cash if the bidder does not plan to develop inventions within the patent scope. It might seem that it would be a good strategy for Party $A$ to win the auction and then simply wait for Party $B$ to develop inventions and then collect royalties through the blocking patent. But if that were so, Party $B$ should be willing to spend the money it would have spent on royalties in bidding on the auction. The auctioned right should generally be worth the most to the party that expects to do (or, if the auction occurs too late, has already done) the most development in the relevant technological field if it were to win the patent.

Nonetheless, an all cash auction might depress research and development, because the funds spent on the auction are diverted to the government. This is not entirely a social loss, for the government can use the auction revenues to reduce taxes and to subsidize new spending. Even if research and development produces particularly high social returns, the government could use auction revenues to subsidize research and development in any number of ways, for example through grants or tax subsidies. It may, however, be worthwhile for the government to tie the funds received directly to research and development that would benefit the patentee. At the least, this should make a patent auction system easier to enact politically (though admittedly still not enactable in the near future). A simple approach would put the money paid by the winning bidder in trust for the winner bidder to use in research and development. Some litigation might result from disputes about whether spending by the winner was really within the scope of the patent grant, ${ }^{158}$ but the problem is not so different from any typically encountered in trust law. Because bidders would anticipate receiving their bids back for research spending through the trust, this should dramatically increase the amount that bidders would offer, as well as the amount that bidders would spend in research and development.

A significant problem with this approach is that it requires bidders to make up-front cash commitments in uncertain technological areas. Sometimes, a technological area will prove a dead

\footnotetext{
157 But see Abramowicz, supra note 52 (noting that a patentee might obtain a patent for its option value when the probability that commercialization will be worthwhile is low).

${ }^{158}$ Arguably, it is desirable to provide a single party with an incentive to argue that research and development spending fell short of the promised amount. For example, the government could hold an auction for the right to sue the winning bidder for spending too little. The revenues from this auction would go to the winning bidder of the R\&D auction, but a successful suit would result in the funds not spent being allocated to the party that wins the right to sue. In litigation, courts would need to evaluate the degree to which spending really was within the research field.
} 
end, yet the auction winner will still have an incentive to spend the funds that it already has committed. One solution is that bidders might promise to spend an amount each year proportional to the auctioned patent's value that year, but this does not necessarily achieve the social optimum, because a patent might be quite valuable even once all useful research has been completed. Plus, this approach would necessitate some means of valuing patents. ${ }^{159}$ A simpler alternative is to have a research subsidy auction, in which the winner is the party that agrees to accept the lowest governmental subsidy per dollar that it commits to research spending. ${ }^{160}$ The winner would also have to pay some fixed amount of cash to the government, so the higher the level of this amount, the greater the subsidy that the winning bidder will insist on. Of course, the government also could set a fixed research subsidy, and then award the patent to the party that agrees to pay the most cash to the government. Either way, the government might structure the auction in a way that would lead it to expect to break even or that would leave it receiving rents from or subsidizing the inventor. A difficulty with patent auctions is that it is difficult to calculate the optimal level of research subsidy, though of course that problem also exists in the existing patent system.

\section{B. Price Auctions}

\section{Least Patent Term Auctions}

If the explicit patent auction awards the patent to the inventor that offers the least term, the effective patent term could be even shorter than with the patent system, especially if auctions occur relatively early in the inventive process. By requiring that each bidder also agree to pay a substantial fixed fee if the bidder wins the auction, then the explicit patent auction could result in longer patent terms, thus reducing spillovers. Long patent terms have a drawback as well, increase in deadweight loss. Least-term auctions reduce the concern, because they ensure that patents are placed in the public domain as fast as possible. Depending on the size of this fixed fee, effective patent terms might still be longer with explicit least-term auctions than in a patent

\footnotetext{
${ }^{159}$ For a discussion of some of the difficulties in patent valuation, see F. Russell Denton \& Paul J. Heald, Random Walks, NonCooperative Games, and the Complex Mathematics of Patent Pricing, 55 RuTGERs L. ReV. 1175 (2003). One possible approach is to use a self-assessment mechanism. Third parties could be invited to make bonded offers to purchase the patents, with the highest offeror receiving a reward (some small percentage of the highest bid); this reward, combined with the possibility that the patentee might accept an offer, give incentives for honest third-party valuation. See Saul Levmore, Self-Assessed Valuation Systems for Tort and Other Law, 68 VA. L. REV. 771, 783-88 (1982) (devising a similar competitive assessment system for valuing real property).

${ }^{160}$ I am grateful to Sam Dinkin for this suggestion.
} 
system, potentially increasing deadweight loss. Effective patent terms, however, could well be lower with explicit least-term auctions for any given level of research investment by inventors, thus decreasing deadweight loss. One reason is that an explicit auction could, and ideally should, take place earlier than an award of a patent, thus avoiding more duplicative activity. An explicit auction channels rent dissipation from a patent race to the least-term auction, so the reduced competition in racing translates to reduced patent term bids.

A more subtle reason that least-term auctions might lead to shorter effective patent terms than the implicit auctions that Duffy describes is that explicit patent term auctions might provide a workable approach in cases in which implicit patent term auctions cannot occur. For example, an exogenous shock might make attractive a technological prospect that previously did not seem worth pursuing, but it is impossible in a patent system for prospective inventors to respond to such a shock by going back in time and beginning their inventive activity any earlier than immediately after the shock. One particularly important form of a shock, albeit one endogenous to the patent system, is the development of another invention, without which development of the improvement would be impossible. "To the extent that the patent system is willing to enforce patents on ... new but obvious ideas," Duffy has noted, “the unexpected development could trigger a flood of patent applications trying to secure monopoly rights to the new but obvious ideas that have suddenly come to have evident economic value.”161

Duffy and James Dabney have argued in a recent certiorari petition ${ }^{162}$ challenging the Federal Circuit's doctrine on the nonobviousness requirement ${ }^{163}$ that such shocks provide a strong defense of the nonobviousness requirement for patenting. ${ }^{164}$ The case involves a patent for an automobile gas pedal that combines two features of former gas pedals, adjustability (long familiar in the art) and electronic control (previously patented but relatively new in the art). ${ }^{165}$

\footnotetext{
161 Duffy, supra note 20, at 505.

162 Petition for a Writ of Certiorari, KSR Int'l Co. v. Teleflex Inc., No. 04-1350 (U.S. filed Apr. 6, 2005), available at 2005 WL 835463.

163 The Federal Circuit has generally insisted that for a combination invention to be nonobvious, there must exist a motivation, suggestion or teaching for that combination in the prior art. See, e.g., In re Kotzab, 217 F.3d 1365, 1370 (Fed. Cir. 2000) (holding that "to establish obviousness based on a combination of the elements disclosed in the prior art, there must be some motivation, suggestion or teaching of the desirability of making the specific combination that was made by the applicant”).

${ }^{164}$ Petition for a Writ of Certiorari, KSR Int'l, No. 04-1350 at Part IV ("The Federal Circuit 'test' ignores that exogenous changes-i.e., economic, regulatory or technological changes not attributable to the work of the alleged inventor-can create new possibilities that can be exploited, or new needs that can be satisfied, with technological trivial combinations of existing technology.”).

165 Teleflex Inc. v. KSR Intern. Co., 298 F. Supp.2d 581, 586-92 (E.D. Mich. 2003), vacated and remanded, 119 Fed. Appx. 282, 2005 WL 23377 (Fed. Cir. 2005), petition for cert. filed, 73 USLW 3623 (Apr. 6, 2005) (No. 04-1350).
} 
The race to invent the combination of these two features could not begin until the invention of the electronic control, so rents could not be completely dissipated through a race for a shorter patent term. Duffy and Dabney might be correct that courts should be more willing than they are to declare such inventions obvious, thus placing them in the public domain, even where no explicit suggestion to combine the old elements exists in the prior art. This is an imperfect solution, however. Even an obvious invention requires money to develop, and if demand for the invention is uncertain, third parties will be able to free ride off the information produced by the commercialization efforts of the first inventor. Anticipating this, no one might develop the invention immediately.

Because implicit least-term patent auctions cannot occur after the occurrence of exogenous shocks, explicit least-term patent auctions provide an alternative means of efficiently dissipating rents and avoiding the danger of unduly long patent terms that increase deadweight loss. Lowering the obviousness threshold might be a less efficient approach in cases in which inventions will need further development. This analysis suggests a relatively modest use of explicit declining patent-term auctions. With the issuance of any new patent, the Patent and Trademark Office could, with appropriate statutory authorization, auction the right to develop inventions combining the newly patented invention with any previous patented invention. The Office could hold such an auction after a request from any private party for an auction to combine. The winning bidder would be the party willing to pay the preset fixed fee who offered the least patent term. Of course, the winning bidder's rights would not trump those of any party that previously filed a patent. If there were no winning bidder, then the combination, if still nonobvious under prevailing doctrine, would remain for a subsequent patentee to claim. ${ }^{166}$

\footnotetext{
166 At least three difficult questions about the design of such an auction would remain. First, would the winning bidder be required to perfect the intellectual property right by subsequently filing a patent detailing the combination? An argument against such a requirement is that it would needlessly increase transactions costs. An argument for is that it would ensure appropriate disclosure of the best means of achieving the combination.

Second, would the winning bidder still be required to show that the combination is nonobvious? This might be difficult to establish, because the mere request for the auction could count as prior art. The danger of not requiring nonobviousness is that the explicit auctions might unnecessarily create patents of at least some finite length, given the requirement that a cash payment accompany the winning bid, leading to deadweight loss. The occurrence of an explicit least-patent-term auction, however, generally makes concerns about obvious inventions less salient, because obvious inventions that require little development will receive relatively short patent terms, and when inventions are obvious but second-mover advantages exist, some patent protection may be optimal.

Third, would the auctioned right supersede the rights of inventors who have pending patent applications or who have invented but have not yet filed patent applications? A particular concern is that the auction system might lead inventors to hold off patenting until they have also patented combinations of the original invention and other inventions, lest someone else obtain rights to the combination.
} 


\section{Price Auctions}

Price is the most obvious candidate for an alternative auction currency. After all, the price criterion is a principal focus of the classic Demsetzian auction. Moreover, pricing above marginal cost directly causes deadweight loss. Allowing the patentee to price above marginal cost is the public's central concession in the patent bargain, but a price auction in theory would identify the private party that is willing to charge the least amount over marginal cost. All else equal, it is more efficient for a patentee to make a concession equivalent to a certain amount of money in the form of lower prices than in the form of a cash payment to the government. The price concession reduces an economic distortion; the cash payment to the government does not. ${ }^{167}$ This is the flip side of the point that it is generally more efficient to raise a given sum in taxes through the general income tax system than by imposing the tax on a single particular product (unless an externality provides a separate justification for the tax on that product). ${ }^{168}$

Ian Ayres and Paul Klemperer have noted that a reform reducing the price that a patentee charges below the monopoly level is particularly appealing because of what they label the "stationarity intuition." "Because an unconstrained patentee maximizes profits by choosing the quantity or price that reaches a flat point - what mathematicians call a stationary point - on the profit surface, small changes away from the profit-maximizing price or quantity will have only second-order effects on profits," they argue. ${ }^{169}$ "But small decreases in price will have first-order effects on the deadweight loss - so that reductions in price have larger impacts on welfare than profits." 170 Ayres and Klemperer use a simple but plausible example to show "that reducing the monopoly price by $10 \%$ might only reduce the patentee's profits by $1 \%$, but can reduce the social costs of monopoly by $19 \% .{ }^{171}$ If price auctions can lead patentees to make even slight concessions on price, social welfare might increase by considerably more than the concessions to the patentees.

\footnotetext{
167 The cash payment to the government, however, may reduce the need for other taxes, which themselves may cause economic distortions. See, e.g., Charles L. Ballard \& Don Fullerton, Distortionary Taxes and the Provision of Public Goods, J. Econ. PersPeCtives, Summer 1992, at 117 (discussing the economic distortion associated with taxation). Nonetheless, this distortion is generally thought to be less than the distortionary effect of monopoly pricing created by patents. See Michael Abramowicz, Perfecting Patent Prizes, 56 VAnderbilt L. Rev. 115, 201-02 (2003).

168 See, e.g., Frank P. Ramsey, A Contribution to the Theory of Taxation, 37 ECON. J. 47 (1927).

169 Ayres \& Klemperer, supra note 69, at 989.

${ }^{170}$ Id.

${ }^{171}$ Id. at 990.
} 
Patent auctions that award the patent to the inventor who offers the least term also eliminate deadweight loss. Because they eliminate deadweight loss entirely in some periods and not at all in other periods, however, they might be less efficient than price auctions that cause some reduction in monopoly pricing over all of a longer period of time. Indeed, Ayres and Klemperer's central argument is that a patent system that provides less power over price but offers a sufficiently longer patent term to make patentees indifferent would be more efficient than the present system. ${ }^{172}$ That does not, however, necessarily mean that the optimal patent term is infinite. ${ }^{173}$ Duffy recognizes that implicit patent term auctions, unlike Demsetzian auctions, do "not attempt to limit the patentee's monopoly power during the term of the patent."174 Longer patent terms, however, would increase administrative costs, and thus a finite term is probably superior to an infinite term in which the patentee has reduced market power. ${ }^{175}$

Once we determine that a finite term is desirable, there is no a priori reason to conclude that the existing patent term is too short. After all, even if the patent term were increased and the patentee's power over price were reduced just enough to keep the patentee's profits the same, the stationarity intuition would still apply, for unless the government directly regulates the prices of products sold by the patentee, the patentee will always choose a stationary point on the profit surface. Nonetheless, the Ayres-Klemperer intuition applies not only to the issue of patent term, but also to the issue of patent scope. Thus, if the structure of the patent system leads to suboptimal patent scope, ${ }^{176}$ then it might be desirable to correct this problem with a patent auction that provides broader scope but insists on some price concessions. Meanwhile, the optimal patent term is probably longer with broader patents, because broader patents reduce transactions costs, ${ }^{177}$ so even if the Ayres-Klemperer argument is insufficient to justify a longer patent term in our existing system, it should be adequate to justify a longer patent term in a system of patent auctions.

\footnotetext{
${ }^{172}$ Id. at 990-93 (noting that this is an implication of Ramsey, supra note 168, applied intertemporally).

173 Ayres and Klemperer acknowledge this point implicitly, noting that a patent of infinite duration might not be possible as a “pragmatic or political matter.” Id. at 1011.

174 Duffy, supra note 20, at 478.

${ }^{175}$ Id. at 478 n.125 (citing Shlomo Yitzhaki, A Note on Optimal Taxation and Administrative Costs, 69 AM. ECON. REV. 475 , 480 (1979) as presenting an analogous optimal taxation problem). For a careful analysis of perpetual patent terms that rejects the concern about the anticommons, see F. Scott Kieff, Coordination, Property \& Intellectual Property: An Unconventional Approach to Anticompetitive Effects and Downstream Access 64-66 (2006) (unpublished manuscript, on file with author).

176 See supra Part II.A.1.

177 See supra note 103 and accompanying text.
} 
Reducing the returns to patentees will necessarily reduce the extent to which patentees will develop their patent rights. That is so whether the returns are lowered by limiting the number of years of the patent, by limiting power over price, or by some combination. The problem might be less severe, though, if a given level of reduced returns is produced through a relatively long patent term with relatively stiff price concessions. Reduced power over price might lead patentees to delay invention or commercialization activities in many cases, ${ }^{178}$ but not to abandon a few altogether. With sufficiently long terms, it will likely eventually be in the patentee's interest to develop the invention. If the term is short, an invention might fall into the public domain, and no one might have adequate incentives to commercialize it. ${ }^{179}$ On balance, the patent terms for an optimal explicit price auction would likely be considerably longer than the current patent term, and price concessions would dissipate deadweight loss.

The patent term length is not, however, the only parameter that the government would need to set if implementing explicit price auctions. As with an explicit patent term auction, the winner in an explicit price auction would also need to be required to pay some fixed fee to the government. Otherwise, someone could promise to price an invention only just above marginal cost, and then the patentee would have virtually no incentive to develop the invention further. If conducting an explicit price auction, the government thus must determine the appropriate fixed fee. If the fixed fee is too high, then patentees will make only minimal concessions on price, and deadweight loss might be even higher than in a regime of implicit patent auctions. If the fixed fee is too low, then the risk of nondevelopment is high. Bidders would seek to obtain patents largely for their option value, promising fabulous price concessions in the hope that demand will turn out to be higher than expected, but then probably not delivering a product. An explicit price auction might reduce the costs associated with the risk of reduced invention within the patent scope, but it does not remove the tradeoff that all patent auctions present between deadweight loss and insufficient invention incentives.

The smooth administration of explicit price auctions is, in any event, by no means guaranteed. The optimal design of a patent auction is not entirely straightforward even when an intellectual property right covers an invention that corresponds to a single undifferentiated

\footnotetext{
${ }^{178}$ Such activities may become more attractive over time for the same reason that invention may become more attractive over time in Barzel's model, that the demand for an invention may increase over time. See Barzel, supra note 30, at 349.

${ }^{179}$ See supra Part I.B.
} 
consumer product. Such an invention could be sold to the public at a fixed price, and thus the auction might award the patent to the party that agrees to sell the product for the lowest price. It might, however, not be efficient for the invention to be sold at a fixed price. Price discrimination can reduce deadweight loss, ${ }^{180}$ and so mandating a fixed price might eliminate an efficient practice that already partially achieves the goal of patent auctions. Thus, a more appropriate auction design might award the intellectual property rights to the bidder who offers the lowest maximum price. Even this might not be efficient, however, because the bid reflects only a portion of the price schedule. Ideally, bidders might submit more elaborate price schedules, but the informational demands of comparing the effect of different price schedules on deadweight loss would be formidable.

The problem becomes more severe once we relax the assumption that the patent right necessarily corresponds to a single product. We have seen that one of the principal advantages of explicit auctions is that they might convey intellectual property rights to an entire field, so the assumption is particularly unrealistic in the context of explicit auctions. If the field consisted of a class of drugs, for example, then the auction might demand a bid for a single price to be applied to each of the drugs. But that might well be inefficient, particularly if some of the drugs required considerably more development expense than the others or if consumer demand varied considerably from one drug to another, because it would distort the patentees' incentives to develop the different drugs. The problem would be more severe still if the field auctioned encompassed a wide range of products with very different price levels. It would be especially problematic if the primary value of patents is that they might be licensed to other firms, which might use the licenses more or less intensively. In this case, efficiency requires individualized pricing, which cannot easily be accomplished in advance.

There are, however, at least three possible ways of implementing explicit price auctions even when the products that the auction right might lead to are heterogeneous or even unknown. The first is that a compulsory license regime might be established, with a governmental agency determining a fair price for licensing of the patent. The auction winner would be the party that agrees to license patents for the lowest percentage of the fair price. Most of the familiar defects of compulsory licensing regimes are defects of this proposal as well. The government might not

\footnotetext{
${ }^{180}$ For an analysis of the relevance of price discrimination to intellectual property policy, see Michael J. Meurer, Copyright Law and Price Discrimination, 23 CARDOZO L. REV. 55 (2001).
} 
be well equipped to determine the fair or efficient price at which patents should be licensed, ${ }^{181}$ and compulsory licensing likely will involve greater transactions costs than a property rule that gives full pricing authority to the patentee. On the other hand, one defect of compulsory licensing would be less of a problem: the danger that the licensing board might be systematically too pro- or anti-patentee. To the extent that bias on the board's part is anticipated, the ex ante auction bids will adjust to correct for it.

A second approach is that a patent might be awarded to the bidder who offers to accept the smallest proportion of patent damages. Under this approach, the patentee would not be able to obtain injunctive relief, ${ }^{182}$ and any damages calculated by a court in the usual way would be discounted by the patentee's winning bid. As Ayres and Klemperer have observed, reducing damages is one way of reducing a patentee's market power. ${ }^{183}$ With reduced damages, if the patentee attempts to charge the monopoly price, some degree of entry will likely occur, either as a result of licensing agreements on more attractive terms than could be obtained or from infringers who determine that some degree of infringement will be profit-maximizing given the reduced damages. Alternatively, the patentee might simply lower prices itself as a way of preempting competition. One way or another, reduced damages will mean lower prices and less deadweight loss, with greater concessions on damages translating into greater concessions on price. ${ }^{184}$ This approach is akin to the compulsory licensing board in that the government

${ }^{181}$ For an empirical analysis purporting to show that compulsory licenses do not deter innovation, see Colleen Chien, Cheap Drugs at What Price to Innovation: Does the Compulsory Licensing of Pharmaceuticals Hurt Innovation?, 18 BERKELEY TECH. L.J. 853 (2003). This may be an area, however, in which economic theory is more useful than tentative empirical results. If compulsory licenses lower the return to innovation, there will be less innovation. Even if compulsory licensing does not lower the return to innovation overall, it may change the distribution of innovation, and the case for compulsory licenses then depends on whether the government does better than the market in determining which innovations should be pursued.

182 There are two disadvantages of eliminating injunctive relief. First, some infringers might be judgment-proof. See The Changing Limits of Injunctive Relief, 78 HARV. L. REV. 997, 1001-02 (1965) (arguing that judgment-proof defendants may provide one justification for injunctive relief). An antidote would be to require alleged infringers to obtain bonds ensuring that they will be able to obtain damages. Second, in a liability rule regime, it may be more advantageous to infringe than to negotiate whenever the infringer expects that the courts will underestimate damages or that the patentee will not be able to afford litigation. Cf. Thomas F. Cotter, An Economic Analysis of Ehnanced Damages and Attorney's Fees for Willful Patent Infringement, 14 FED. CIR. B.J. 291, 310 (2004) (noting several reasons that patentees may fail to enforce their rights). A patent regime without injunctive relief, however, might compensate for this by imposing a small damages multiplier fixed in advance, which would then be discounted in an explicit auction.

183 Id. at $1028-31$.

${ }^{184}$ A variant on this approach would be to award full damages but only with some positive probability, and the winning bidder would be the party that offers the lowest probability. The idea that "probabilistic patents" in which enforcement occurs with less than certainty is Ayres and Klemperer's primary proposal. Id. at 993-1013. Conceivably, it might be more efficient than a regime of reduced damages, if it reduced litigation cost. If that is so, however, the litigation system in general should provide for only probabilistic enforcement of legal rights, with damages set at a multiplier of the usual damages level in the cases in which the rights are enforced. See, e.g., David Rosenberg \& Steven Shavell, A Simple Proposal to Halve Litigation Costs (Harvard Law and Econ. Discussion Paper No. 513, Apr. 2005), available at http://papers.ssrn.com/abstract_id=729444 (offering such a proposal). 
eventually would need to determine the damages from infringement, but such determinations would be made ex post by courts, and in all likelihood, far more occasionally. A comparison between the two approaches depends on the relative transactions costs of the two approaches as well as on the institutional competence of the licensing board versus that of the courts.

A third approach is direct price regulation of the products the patentee produces, with the winning bidder the patentee who offers to sell each product or service for the lowest multiple of the regulated price determined by a government agency. This approach would require the government to make the most decisions, because the other two approaches would save the government the trouble where the patentee enters into a voluntary licensing arrangement or settlement. It is thus likely to have the highest transactions costs. Nonetheless, it might be useful in cases in which there are significant economies of scale in producing the relevant good. In such cases, there might be a wide range of discounts that auction bidders could offer under the first two approaches without producing even the threat of a single competitor and thus without affecting price. If no bidder can afford to offer a discount beyond this range, then the auction would fail to dissipate rents. A price regulation auction thus might be the only means of effecting relatively small price concessions.

\section{MORE MODEST PROPOSALS}

Even if we accept that there are at least some contexts in which broader patent scope might be desirable, the technical challenges of running a patent auction system are formidable. We have seen that the government might err in deciding which rights to auction, and that the government might fail to provide an optimal tradeoff between concerns about deadweight loss and insufficient invention incentives in designing the structure of the auction. These problems are difficult enough in theory, but even if sound theoretical answers could be developed, interest group pressures might well lead the government to stray from the optimal path. If patent auctions are to be practical, there must be some means of minimizing the danger of governmental errors. $^{185}$

\footnotetext{
185 A much more ambitious approach might be to use information markets to decide when auctions should occur and to identify the bidder most likely to maximize social benefits. See Michael Abramowicz, Information Markets, Administrative Decisionmaking, and Predictive Cost-Benefit Analysis, 71 U. CHI. L. REV. 933 (2004) (providing an overview of the emerging literature on information markets); Michael Abramowicz, Information Markets for Patent Races (2006) (unpublished manuscript, on file with author) (developing this idea further).
} 
Part IV.A points out that patent auctions might limit the number of participants in a particular field, without limiting competition to a single inventive entity. A particularly promising approach is to use an R\&D auction to distribute the rights and then allow auction winners to negotiate to divide technological opportunities, thus reducing wasteful duplication. Part IV.B considers the alternative of "patent scope auctions," in which an individual patentee could opt for extended patent rights that the government would auction. The rules of the auction encourage patentees to seek broader patents only to the extent that subsequent research would be particularly redundant and costly.

\section{A. Auctions with Multiple Winners}

A compromise approach would use patent auctions with multiple winners, who would receive a right to race rather than a right to exclude. Two or more auction winners would be entitled to seek patents in the relevant area. Other parties would not be entitled to seek patents or to sell their inventions to the auction winners; any inventions in the field they created would be placed in the public domain. The auction winners would have exclusive rights for only a limited time, perhaps ten or fifteen years, making experimentation with this approach more feasible than experimentation with full-fledged patent auctions. This approach borrows from the literature on research tournaments, which has shown that it often will be efficient for the tournament sponsor to limit entry, for example by holding an auction. ${ }^{186}$ Of course, such an approach might not afford all of the benefits of a full-scale patent auction, because patents would still be of traditional scope and duration. But there may be less inefficient duplication in a race with two competitors than in a race with many competitors.

The government might still make errors in administering the regime, but mistakes would be less costly. Because the winners must still obtain traditional patents, there would be no danger that the system would increase deadweight loss. Implicit coordination might inefficiently limit total research expenditures, but the costs would likely be lower than with full-fledged auctions. Indeed, coordination should perhaps even be allowed or encouraged, if an R\&D auction is used to award the racing rights and thus avoids the danger of insufficient research expenditure. The winners might still decide to race in a particular area, especially if they believe that competition

${ }^{186}$ See supra notes 5-6 and accompanying text. 
is more likely to produce a solution. But they might agree to avoid wasteful competition, maximizing the effect of the research dollars that they have committed. An R\&D auction with multiple winners thus potentially can provide as great a benefit in reducing inefficient duplication as a full-fledged patent auction, without the cost of reduced total investment expenditure. Deadweight loss would increase only to the extent that agreements reduce inventing around, but even such reductions might be efficient. Perhaps best of all, the government would not need to decide about the desirability of fostering or limiting competition in any particular technological area within the scope of the auctioned right.

\section{B. Patent Scope Auctions}

An alternative means of minimizing governmental involvement is to give a single private party a financial incentive to determine when to call for an auction that would provide a broader right than a patent on any single invention. One reason that patent scope might be relatively narrow, we have seen ${ }^{187}$ is that the patent office might be ill equipped to make ad hoc judgments about patent breadth, because patent examiners have no way of determining what breadth would maximize economic efficiency. And so patent law restricts patent breadth to the invention claimed in the patent application, even when a broader patent might limit the wasteful duplication associated with inventing around. The challenge is devising a mechanism that would incentivize a private party to request an auction for a relatively broad right only in those cases in which such an auction would produce greater social benefits than social costs.

The mechanism must provide incentives for the private party to distinguish wasteful duplication from valuable additional inventive activity. The less the extent to which hypothetical new products will be mere economic substitutes for existing products, the worse the case for extended patent scope. Consider the extremes: an entirely unrelated product and a perfect economic substitute, assuming that there are no other spillovers from the development of these products. ${ }^{188}$ Suppose that the patentee has received a patent on $A$, and $B$ is an entirely unrelated product or technological area, whose development and sale will have no effect on the sales of $A$. There might still be an argument for awarding the patent on $B$ to $A$, because it would increase the incentive to develop $A$. But the case would be weaker than the case for holding a patent auction

\footnotetext{
${ }^{187}$ See supra Part II.A.1.b.

${ }^{188}$ The assumption of no spillovers does not affect the case for the ultimate proposal. See infra text accompanying note 191.
} 
for $B$, and our goal here is to find a less radical approach than full-scale patent auctions. So, the patent on $A$ at least presumably should not be extended to $B$. There also seems little reason to extend patents to complements of the products invented.

Suppose, however, that it would be possible for a third party at some additional cost to develop $B$, a perfect substitute for $A$. Although $B$ is based on a different technology, the fact that it is a perfect substitute means that from the perspective of consumers will be no better or worse, and cost no more or less. In this case, an ideal patent system should extend the patent to $B$. The only possible benefit of $B$ in this hypothetical is that its existence will lower consumer prices, but if such lower prices were desirable, those could be obtained simply by having the government auction a right to license $A$ to any third party (barring the $A$ patentee from participating in the auction). ${ }^{189}$ A patent system that rejects this approach, for example on the ground that this would unduly lower the incentive to develop $A$ in the first place, should still more forcefully seek to stop development of $B$. Such development would have the same economic effects, but would require independent development expenses that are socially wasteful. At least, extending the patent to $B$ and then holding an auction for a license to the technology certainly would be better than confining the patentee to $A$, though we will not further consider the merits of the license auction here.

In reality, of course, very few products will ever be quite like $B$, but there will be a continuum of potential product areas and technological development from $B$ to $C$. While it might be very difficult as a theoretical matter to identify the optimal cutoff, patent law ideally should award technological areas that are sufficiently close to $B$ to the patentee of $A$, while not awarding areas that are quite close to $C$. Patent law itself does not have the technology to do this, but the patentee of $A$ might be in a very good position to identify any technological areas that are quite close to $B$ on the continuum. Our mechanism will thus allow the patentee of $A$ to call for an auction of any technological area, but give incentives for the patentee to do this only when the technological area is in fact quite near the $B$ end of the continuum. Conceivably, it might be the case that no technologies turn out to be sufficiently close to $B$ to qualify for increased patent scope, but the mechanism at least allows for efficient expansions of patent scope.

\footnotetext{
189 Ayres and Klemperer suggest the possibility of such a "duopoly auction” as a means of reducing patent pricing and thus deadweight loss. See Ayres \& Klemperer, supra note 69, at 1031-32.
} 
The mechanism would work as follows: A recent patentee could call for an auction of a patent that would cover a particular technological area, though that patent would not block any existing patents in that technological area. It would be the patentee's responsibility to define the technological area to be auctioned, though the definition could be based either on technologies or directly on economics. For example, the patentee might define the patent to cover any products having a sufficiently high cross-elasticity of demand with its own product, and the definition might explain how cross-elasticity would be measured. The patentee would have an incentive to find a definition that would minimize litigation, and if such a definition were impossible, the patentee would have less of an incentive to call for the auction in the first place.

There would be two significant catches: First, the patentee who calls for the auction could win it only by paying some substantial markup over the next highest bidder. For example, if the markup were $200 \%$, then the patentee could win the patent only by bidding at least three times the amount of the next highest bid. The patentee would pay no more than the markup amount, and the auction would be a second-price auction for all other participants, ${ }^{190}$ so all participants will have incentives to offer honest valuations. Second, if the patentee loses, the patentee would have to pay a substantial fine, perhaps set at some percentage of the winning bid, and before the auction takes place, the patentee would have to provide a bond to cover any possible such fine. A patentee will thus not call for an auction if it expects that there is a great possibility that it will lose the auction. From a social standpoint, an auction that the patentee loses could have considerable social costs, particularly if the patentee is the most efficient developer of the technology but not by so great a margin that it wins the auction. As a result, the fine must be set high enough to make this an extremely unlikely outcome. It also might be desirable to provide some financial incentive for bidders to keep the auction competitive, for example providing the highest bidder other than the patentee some percentage of that bidder's bid, to be paid by the patentee.

This mechanism should lead the patentee to extend patent scope only to technological areas in which inventive effort would be relatively duplicative of the effort placed into its own invention. If there is no market overlap between a patent of the patentee and the new technological area, then the patentee should not be expected to bid any more than a third party,

190 See supra note 93 (discussing the mechanics and strategy of a second-price auction). 
and thus if there is any markup at all, the patentee will not request an auction. Suppose, however, that a particular technological area covers one other product, which would be a perfect substitute for the patentee's own product. Without the perfect substitute, the patentee can earn some rents $r$ from the patent, but if a competitor develops and markets the perfect substitute, the patentee and the competitor will each earn only earn some proportion $p$ of these rents. The patentee thus stands to lose $r(1-p)$ from the extended patent right and, placing aside the danger of the penalty for analytic simplicity, should thus be willing to bid up to this much. The competitor, meanwhile, would bid only $r p-c$, where $c$ is the cost of developing the perfect substitute. Given the assumption that a perfect substitute does not expand the market for the product, $p$ can be no more than 0.5 , and might be considerably lower as a result of price competition after the substitute is introduced. Thus, the patentee's bid will necessarily be greater than the second highest bidder, if all bidders are rational and have the same information. The difference will be greater, the larger the value of $c$.

As a result, the patentee will have a greater incentive to call for an auction (1) when the relevant technological area is a relatively strong substitute for its own products, and (2) when technological development of these substitutes would be relatively expensive. This is precisely what is socially optimal. Of course, whether the system produces socially optimal results depends critically on the value of the markup. To the extent that research generally produces spillovers, ${ }^{191}$ even research into a perfect substitute could have some value to society. This does not mean, however, that the auction mechanism is ill advised; rather, it means that the markup should be relatively high. Similarly, the costs of broad patent protection, for example to consumers, and the danger that a patentee might call for an auction for anticompetitive reasons might justify a high markup, but they too do not mean that the auction mechanism itself is illadvised. Calculating a markup percentage is beyond the scope of this Article, but the ideal approach would be empirical. If the government were to create a program of this kind, it could start with an extremely high markup and then evaluate the results. If too few patentees opt in, the markup gradually could be lowered.

Patent scope auctions admittedly are but a weak substitute for the patent auctions described earlier. One of the principal advantages of full-scale patent auctions was the possibility

${ }^{191}$ See supra note 38 and accompanying text. 


\section{PATENT RACES VS. PATENT AUCTIONS}

that property rights could be provided at a very early stage, eliminating the duplication associated with racing and providing an additional incentive to invest early. This will not occur with patent scope auctions, which can occur only after someone receives a patent. No one will likely have an incentive to propose a patent scope auction in a field unrelated to a patent the proposer already owns, because in such a case the proposer would be unlikely to be able to outbid all others by a substantial margin. An additional consequence of this is that patent scope auctions might not succeed in producing property rights that are as broad as is socially optimal. Even if it would be socially optimal for a property right to cover all of a technological field, patentees will have incentives to request patent scope auctions only for close substitutes for their own inventions. Patent scope auctions might well cover multiple closely related products, but a patentee would not have an incentive to select a field that has a wide range of potential applications.

Patent scope auctions as described here would be limited in another way: They would only broaden patents along the dimension of technology, not also along the dimension of time. In a separate Article, I suggest a similar scheme that could be used across the time dimension as a means of combating the danger of patent underdevelopment. ${ }^{192}$ Such a mechanism could be applied also to a patent broadened across time with a patent scope auction. There are sound reasons, however, not to combine the two dimensions into a single auction mechanism. First, the optimal time for broadening the technology scope of a patent will usually be shortly after the patent issues, but the optimal time for determining whether to extend a patent term might be nearer the end of the patent term. ${ }^{193}$ Second, the relevant markup percentages might be different, and indeed markups should perhaps be much higher for patent scope auctions, because these are more likely to lessen inventive activity than patent term extension auctions, which give patentees additional incentives to invent. Third, after a patent scope auction that a third party wins, the law would need to bar a transfer of the patent back to the proposer; otherwise, third parties would bid as much as the proposer (less the cost of transfer), and the mechanism might not work properly. In a patent term extension auction, by contrast, the patent should be transferable back to the original patentee after the end of the original patent term. ${ }^{194}$

\footnotetext{
192 See Abramowicz, supra note 50, at 47-53 (introducing a proposal for patent term extension auctions).

193 Id. at 41 (noting the undesirability of a policy lever that must be exercised at the beginning of the patent term).

${ }^{194}$ Id. at 49 (“[T]his assures that . . . the difference between the original patentee's valuation and the third party’s valuation is
} 


\section{PATENT RACES VS. PATENT AUCTIONS}

\section{CONCLUSION}

The analysis of patent auctions might provide a tentative answer to a broader question of why auction mechanisms, such as the one Demsetz proposed for natural monopoly regulation, are not more common. Demsetz's property rights theory can serve as a foundation for a criticism of Demsetz’s separate auction proposal. In his most famous work, Demsetz argued that “property rights develop to internalize externalities when the gains of internalization become larger than the cost of internalization.”195 The task of delineating and enforcing property rights, Demsetz recognized, is costly. The ultimate challenge, however, is not merely to delineate and enforce property rights, but to do so in a socially optimal way. Auction proposals are least likely to be successful when it is unclear what right should be auctioned or what procedure should be used to designate the auction winner. This point undermines Demsetz’s separate proposal for natural monopoly auctions. Governments might not do an effective job of identifying in advance a socially optimal set of quality requirements, and they also might not effectively compare nonprice aspects of auction bids. ${ }^{196}$ In intellectual property, the problem is even more severe, as the government at least must arrive at an auction design that will ensure an appropriate balance among concerns such as inefficient duplication of effort, nondevelopment of patents, and deadweight loss. In government auctions that do occur, such as for spectrum rights, design problems might be less severe.

This Article has shown that patent or natural monopoly auctions likely would be inferior to the status quo, not that they necessarily will be. The status quo mechanism for distributing property rights should be maintained absent a strong showing that an alternative is superior, but that does not mean that evolutionary forces will have given us an optimal system for allocating property rights. Demsetz's property rights theory paid more attention to the question of when

attributable to the benefit of development of the patent within the original patent term, and not to some other factor that makes the patent particularly valuable to the patentee.”).

195 "Increased internalization, in the main, results from changes in economic values, changes which stem from the development of new technology and the opening of new markets, changes to which old property rights are poorly attuned.” Harold Demsetz, Toward a Theory of Property Rights, 57 AM. ECON. REV. 347, 349 (1967).

196 A principal criticism of the Demsetz approach is that it provides no means of aggregating quality and price. Richard Posner proposed that quality might be assessed in combination with price by initially allowing potential suppliers to solicit contracts with consumers and then awarding the contract to the producer who is able to obtain the highest dollar volume of commitments. See Richard A. Posner, The Appropriate Scope of Regulation in the Cable Television Industry, 3 BELL J. ECON. MGMT. SCI. 98,115 (1972) (suggesting that this might alleviate the difficulty of determining the bid offering the best combination of price and quality). Among the potential challenges of such a scheme is that preventing monopolists from reneging on vague quality commitments may be difficult. See Oliver Williamson, Franchise Bidding for Natural Monopolies-In General and with Respect to CATV, 7 BELL J. ECON. 73, 80-82 (1976) (discussing the difficulties of ascertaining quality in a Demsetzian auction). 
property rights develop than to the question of the mechanism by which they develop, ${ }^{197}$ or to the mechanism used to distribute new property rights once recognized. ${ }^{198}$ Property rights might tend to evolve when such evolution would be efficient, but greater skepticism is appropriate in assessing any claims that the property rights that do evolve will be distributed through an efficient mechanism. ${ }^{199}$ Systems that recognize property rights in prospectors such as inventors might naturally emerge through common law decisionmaking. Evolution will leave entrenched interests whose rents an auction system, the creation of which requires centralized action, might dissipate. And so legislators might not adopt even an efficient auction mechanism. The immediate task, however, is not development of legislation, but development of theory, to establish more clearly whether relatively modest experimental use of auctions, such as this Article's suggestions of patent auctions with multiple winners or patent scope auctions with a very high markup, could improve social welfare. Market mechanisms are largely alien to the legal system, but they hold the potential for improving decisionmaking by aggregating dispersed information, allowing for finely tuned policy decisions that we ordinarily would not want to leave to individual decisionmakers’ discretion.

\footnotetext{
197 See, e.g., Robert P. Merges, Intellectual Property Rights and the New Institutional Economics, 53 VAND. L. REV. 1857,1868 (2000) (noting that Demsetz "assumed that changed conditions would automatically translate into revised property rights," without considering the political process that would effect this translation).

198 Demsetz suggested that changes in property rights "have arisen in Western societies largely as a result of gradual changes in social mores and in common law precedents." Demsetz, supra note 195, at 349. This does not provide a direct explanation of how institutions for distributing property rights evolve.

199 Even if an auction is efficient, we should not necessarily expect a change from a prospecting system to a Demsetzian auction. See supra text accompanying notes 93-95; see also David D. Haddock \& Lynne Kiesling, The Black Death and Property Rights, 31 J. LEGAL STUD. 545, 564-65 \& n.51 (2002) (noting that Demsetz's analysis leaves the possibility that because of rent seeking, it will not always be the case that resources will be privatized once the benefits exceed the costs).
} 